University of Louisville

ThinkIR: The University of Louisville's Institutional Repository

Electronic Theses and Dissertations

$5-2021$

\title{
Telling principals' leadership stories: administrative perceptions of promoting teacher leadership.
}

Adam Whitney Hicks Ed.D.

University of Louisville

Follow this and additional works at: https://ir.library.louisville.edu/etd

Part of the Educational Leadership Commons

\section{Recommended Citation}

Hicks, Adam Whitney Ed.D., "Telling principals' leadership stories: administrative perceptions of promoting teacher leadership." (2021). Electronic Theses and Dissertations. Paper 3583.

https://doi.org/10.18297/etd/3583

This Doctoral Dissertation is brought to you for free and open access by ThinkIR: The University of Louisville's Institutional Repository. It has been accepted for inclusion in Electronic Theses and Dissertations by an authorized administrator of ThinkIR: The University of Louisville's Institutional Repository. This title appears here courtesy of the author, who has retained all other copyrights. For more information, please contact thinkir@louisville.edu. 
TELLING PRINCIPALS' LEADERSHIP STORIES:

ADMINISTRATIVE PERCEPTIONS OF PROMOTING TEACHER LEADERSHIP

\title{
By
}

Adam Whitney Hicks

University of Louisville

B.A., University of Kentucky, 2005

M.Ed., University of Kentucky, 2006

Ed.S., University of the Cumberlands, 2014

\begin{abstract}
A Dissertation
Submitted to the Faculty of the

College of Education and Human Development of the University of Louisville in Partial Fulfillment of the Requirements for the Degree of
\end{abstract}

Doctor of Education in Educational Leadership and Organizational Development

Department of Educational Leadership, Evaluation, and Organizational

Development

University of Louisville

Louisville, Kentucky

May 2021 
Copyright 2020 by Adam Hicks

All rights reserved 

TELLING PRINCIPALS' LEADERSHIP STORIES:

ADMINISTRATIVE PERCEPTIONS OF PROMOTING TEACHER LEADERSHIP

\author{
By \\ Adam Whitney Hicks \\ University of Louisville \\ B.A., University of Kentucky, 2005 \\ M.Ed., University of Kentucky, 2006 \\ Ed.S., University of the Cumberlands, 2014
}

A Dissertation Approved on

December 18, 2020

By the following Dissertation Committee

Dr. Mary Brydon-Miller, Chair

Dr. Harrie Buecker

Dr. Keith Davis

Dr. Angela Newcomb 


\section{DEDICATION}

This dissertation is dedicated to my beautiful and endlessly supportive wife and family. 


\section{ACKNOWLEDGMENTS}

First and foremost, an enormous amount of gratitude goes to Dr. Mary BrydonMiller for her patience, support, and steadfast encouragement as I made my way through my dissertation journey. Also, thank you to Dr. Keith Davis for your mentorship, high standards, razor-sharp wit, and endless humor. To Dr. Harrie Buecker, your positivity and kind disposition has been a blessing. Dr. Angela Newcomb, thank you for cultivating my interest in teacher leadership from the onset of my doctoral work. I also could not have gotten to the finish line of this doctoral marathon without my University of Louisville Block 19 cohort collaborators. Finally, to my wonderful family, thank you for your unwavering support and love. I've done everything people recommend you don't do during doctoral work — moved, started a new job, and had children — and the fact that I've finished this work is a testament to your love. To Kisha, thank you for the countless nights you spent caring for three children under five years of age as I attended class, for the hours you've spent patiently listening to my ideas, and for being the rock that grounds all of us. Lastly, to Darcy, Nora, and Wyatt, I love you with every fiber of my being, and I hope that I make you proud. 


\section{ABSTRACT \\ TELLING PRINCIPALS' LEADERSHIP STORIES: ADMINISTRATIVE PERCEPTIONS OF PROMOTING TEACHER LEADERSHIP

\author{
Adam Whitney Hicks
}

December 18, 2020

Numerous definitions, leadership roles, and methods of approaching teacher leadership are discussed in various areas of research; however, no efforts have been made to analyze the administrators who consciously cultivate it in their staff. Using a phenomenological design, this study identified twelve administrators - four elementary, four middle school, and four high school principals — who were found to cultivate teacher leadership, and explored both how these leaders defined teacher leadership, as well as examined how they worked to consciously cultivate it among their staff. Burns' Transformational Leadership Theory (1978) is the study's theoretical framework.

The findings of the study outline a new definition for teacher leadership, and report on both what principals believe about teacher leadership (relationships matter, trust teachers, honor time, the importance of school culture, and the power of administrative mentorship) and the structures principals use to promote teacher leadership (formal school structures and systems, professional learning communities, teacher-facilitated professional development, and teacher feedback systems). Ultimately, this study has 
implications for both researchers and practitioners by providing examples of structures, experiences, and systems that promote building-level teacher leadership efforts.

Keywords: teacher leadership, school principal, school leadership, administrative beliefs, school structures and systems, transformational leadership theory 


\section{TABLE OF CONTENTS}

\section{PAGE}

ACKNOWLEDGMENTS.....................................................................................

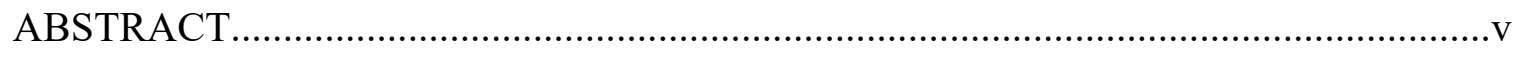

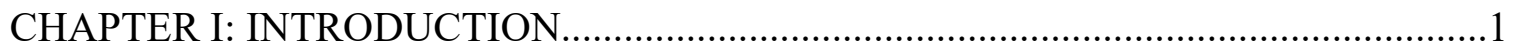

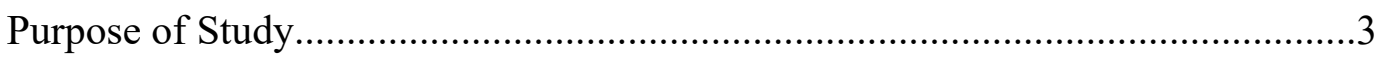

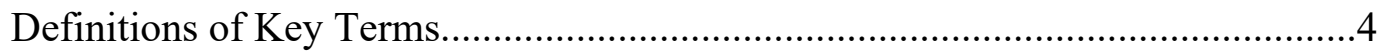

Overview of Research Methodology, Limitations, and Delimitations....................5

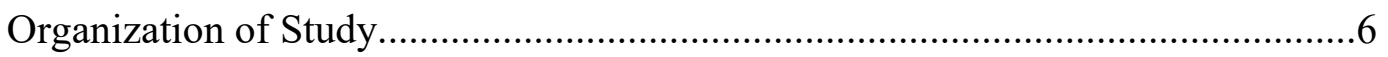

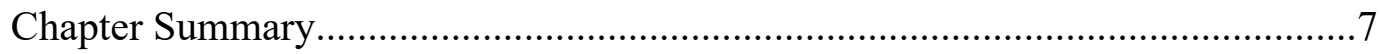

CHAPTER II: LITERATURE REVIEW .......................................................... 8

Defining Teacher Leadership..................................................................

Primary Teacher Leadership Definition..............................................9

Alternate Teacher Leadership Definitions...........................................10

Strengths and Limitations............................................................ 15

Role of the Administrator in Teacher Leadership Efforts................................16

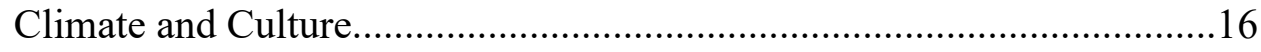

Structures and Systems............................................................... 17

School Specific Roles............................................................. 18

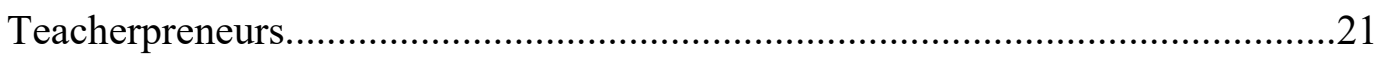

School-Based Decision-Making Councils..........................................22 
Leadership Qualities of Teacher-Focused Administrators...............................24

Transformational Leadership in Educational Settings.....................................26

Summary of Literature Review Findings...................................................28

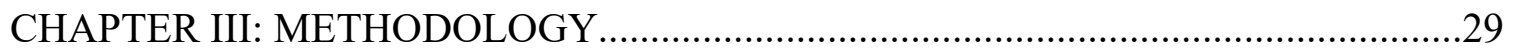

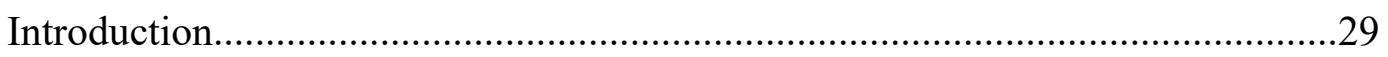

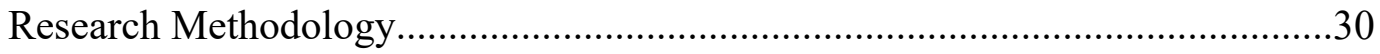

Research Design and Sources of Data.......................................................... 31

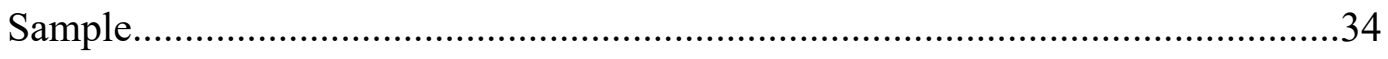

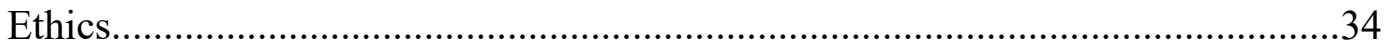

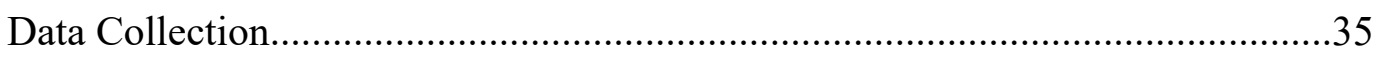

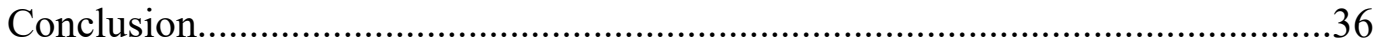

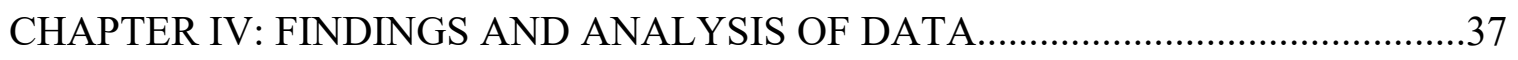

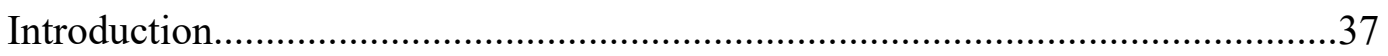

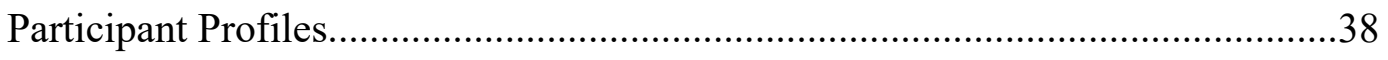

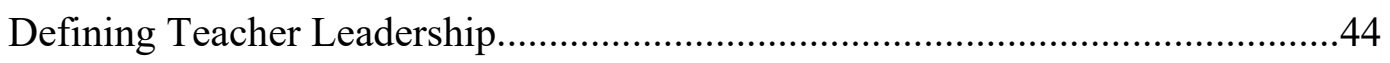

Shared Administrative Teacher Leadership Beliefs........................................49

Relationships Matter............................................................... 49

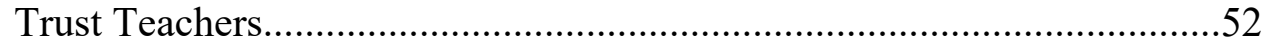

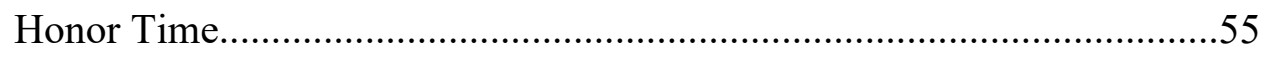

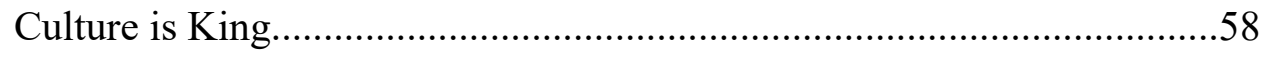

Mentorship Shapes Experience ...................................................61

The Challenges of Teacher Leadership........................................................64

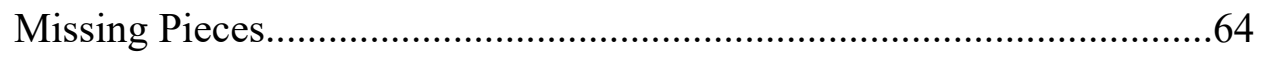




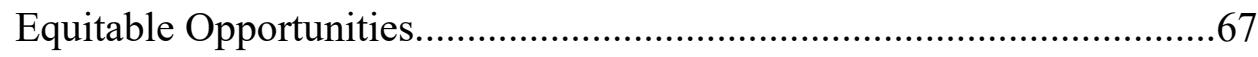

Consciously Cultivating Teacher Leadership..........................................................69

Formal Committee Structures and Systems.................................................69

Professional Learning Communities..........................................................73

Teacher-Facilitated Professional Development..........................................76

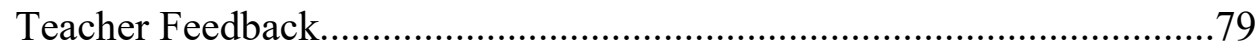

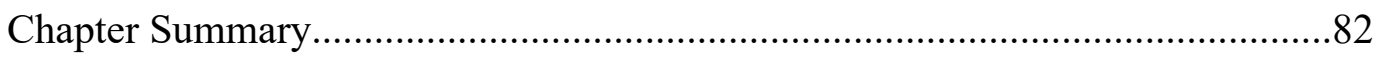

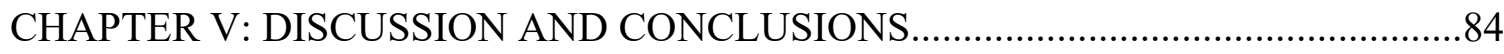

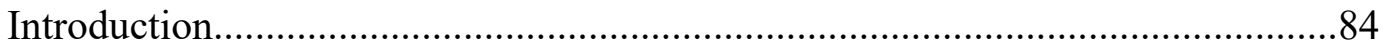

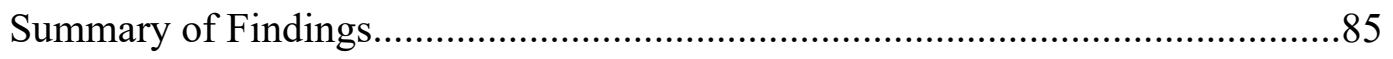

Defining Teacher Leadership....................................................................85

Shared Administrative Beliefs..................................................................86

The Challenges of Teacher Leadership...................................................8

Consciously Cultivating Teacher Leadership............................................8 88

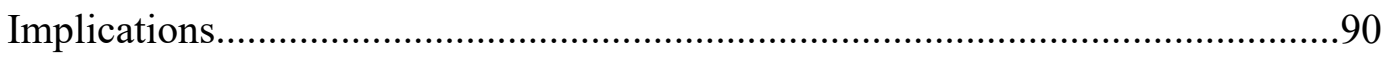

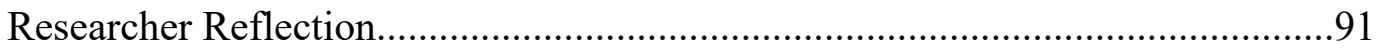

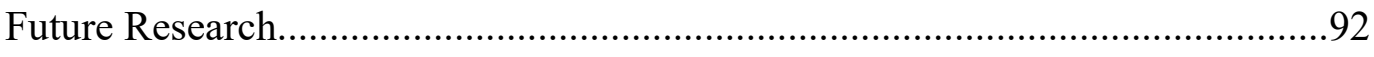

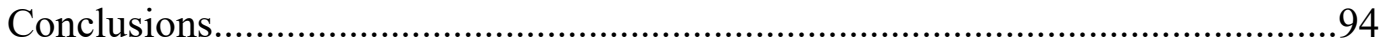

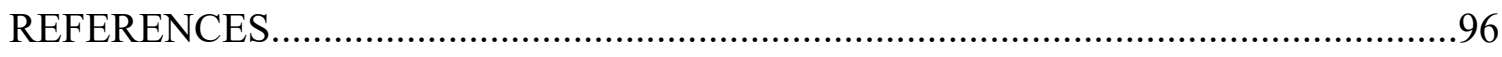

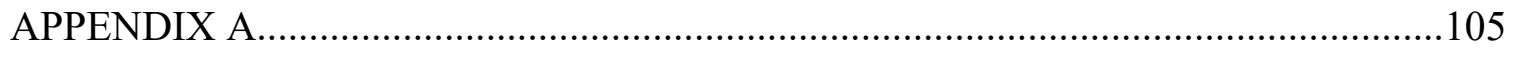

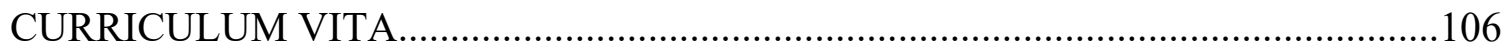




\section{CHAPTER I}

\section{INTRODUCTION}

Two landmark studies have paved the way for teacher leadership research. Hattie (2015) in his ongoing meta-analysis of effective teaching practices notes two areas where teacher leadership has a significant impact on student achievement: collective teacher efficacy and teacher credibility. In an earlier, yet highly influential and widely cited study, York-Barr and Duke (2004) note that one of the key conditions for promoting teacher leadership is "the active support of their principals." (p. 290). Despite these findings, an exhaustive list of seemingly contradictory methods for how a principal can promote teacher leadership has emerged. One perspective is that administrators who conscientiously shape the collaborative opportunities for their teachers, as well as establish their staff's sense of trust and security, can have a positive impact on teacher leadership efforts (Brezicha, Bergmark, \& Mitra, 2015; Minckler, 2014; Williams \& Johnson, 2013). 
An alternate perspective is that teacher leadership can emerge without a principal's intentional structure or involvement (Cheng \& Szeto, 2016; Danielson, 2006; Greenier \& Whitehead, 2016), and can be cultivated solely through teacher-led initiatives, and by teachers immersing themselves into research (Poekert, Alexandrou, \& Shannon, 2016). Creating a shared vision, mission, and cooperative school culture can all be used to impact teacher leadership (Cook, 2014; Danielson, 2006), as can being closely involved with teachers' classroom practice through professional learning communities (Vanblaere \& Devos, 2016).

Where there is large body of research that points to how principals can impact teacher leadership, there are only a handful of studies that look at the beliefs of principals who cultivate teacher leadership. Some researchers have noted the strengths of principals who can identify effective teacher leaders in promoting teacher leadership efforts (Smith, Hayes, \& Lyons, 2017), where others have suggested principals view teacher leadership as an individual effort versus a collective one (Uribe-Florez, Al-Rawashdeh, \& Morales, 2014). Again, these contradictory viewpoints provide marginal insight into administrators' views of teacher leadership, especially among those principals who value it.

Given these inconsistencies, there is immense value in examining the definitions, structures, and beliefs of administrators who consciously cultivate teacher leadership. As Helterbran (2010) notes, "effective leadership can and should be infused among teachers. The principal, to be fully effective, must understand the importance and benefit of sharing leadership for without this understanding to support and foster teacher leadership, 
little good will come.” (p. 364). The need to understand administrators who consciously cultivate teacher leadership is dire, for as Lambert (2003) suggests:

Why is engendering teacher leadership considered difficult by many principals and superintendents? Several reasons come to mind: a philosophy of leadership that situates leadership work within formal authority roles, a hierarchical view of authority and power, and an insistence that if we just find the right 'carrot', the right incentive package, we can coax teachers to take on leadership roles. Such attitudes produce short term, shallow and unsustainable results. Old assumptions bind and confine. (p. 421)

In order to fully understand successful teacher leadership efforts, a study must be done to examine the leaders who consciously cultivate these efforts.

\section{Purpose of Study}

In an educational landscape where only 30 percent of high school principals remain in their same position after three years (Fuller, 2012), and where a lack of selfefficacy and autonomy among teachers leads to teacher turnover (Al-Yaseen \& AlMusaileem, 2013; De Neve \& Devos, 2017), examining the definitions, structures, and shared beliefs of principals who cultivate teacher leadership is critical. Furthermore, where there are multiple instances of teacher leadership being examined from the perspective of teachers (Angelle \& Schmid, 2007; Angelle and Teague, 2014; Cheng and Szeto, 2016; Cook, 2014; Helterbran, 2010; Hulpia, Devos, and Van Keer, 2011; Poekert, Alexandrou, and Shannon, 2016; Smith, Hayes, and Lyons, 2017), there are very few that focus directly on both the role and the perspective of administrators who consciously cultivate teacher leadership (Valentine and Prater, 2011; Vanblaere and Devos, 2016). 
This study aimed to provide clarity to existing teacher leadership research by being structured around four research questions:

Q1. How do administrators define teacher leadership?

Q2. What shared beliefs about teacher leadership exist among administrators who cultivate it?

Q3. What challenges emerge when creating teacher leadership opportunities?

Q4. How do administrators consciously cultivate teacher leadership?

Through analyzing these four research questions, this study's goal was to fill in gaps that exist in the research concerning the actions principals take to create teacher leadership opportunities, as well as to find a shared set of beliefs among principals who cultivate teacher leadership. By focusing on the practitioners of this work-

administrators in the field who have been noted to support teacher leadership — this study also provides actionable steps for both teachers and building-level leaders who hope to promote teacher leadership in their schools.

\section{Definitions of Key Terms}

SBDM. School-Based Decision-Making Councils, or SBDMs, are mandated by Kentucky state law (KRS 106.345) and ensure that teachers across the state have a voice in meaningful decision-making processes. SBDM councils are composed of elected teachers and parents, and are tasked with various governance issues from deciding upon instructional materials and budgetary concerns to hiring a principal if a vacancy occurs (KRS 106.345).

Teacher leadership. Although over a dozen definitions of teacher leadership persist across the body of literature (Childs-Bowen, Moller, \& Scrivner, 2000; Crowther 
et al., 2002; Danielson, 2006; Darling-Hammond, Bullmaster, \& Cobb, 1995; Harrison \& Killion, 2007; Helterbran, 2008; Helterbran, 2010; Katzenmeyer \& Moller, 2001; Krisko, 2001; Lambert, 2003; Murphy, 2008; Reeves, 2008; Sergiovanni \& Starratt, 1998), this study will rely on the York-Barr and Duke's (2004) widely-utilized definition. YorkBarr and Duke define teacher leadership as, "the process by which teachers, individually or collectively, influence their colleagues, principals, and other members of school communities to improve teacher and learning practices with the aim of increased student achievement" (p. 287).

TELL. The Teaching, Empowering, Leading, and Learning — or TELL—Survey is an anonymous, Likert-scale assessment given to every teacher in the state of Kentucky on a two-year basis. In 2017, over 41,500 educators (or $91 \%$ of teachers in the state) responded to the survey (TELL Kentucky, 2020). The survey includes questions on nine topics: Community Engagement and Support, Teacher Leadership, School Leadership, Managing Student Conduct, Use of Time, Professional Development, Facilities and Resources, Instructional Practices and Support, and New Teacher Support. On the Teacher Leadership portion of the survey, Kentucky teachers were asked 18 questions that examine issues such as whether teachers are recognized as instructional experts, and if teachers have an appropriate level of influence on decision making, and if teachers in a school have a role in selecting new teachers and instructional materials and resources.

\section{Overview of Research Methodology, Limitations, and Delimitations}

A qualitative, phenomenological approach was used for the study's research design. Administrators who cultivate teacher leadership were identified through Kentucky's TELL survey results, and a series of semi-structured interviews were 
conducted to help answer the study's research questions. Participants came from twelve schools across four school districts.

There are several limitations of the study. The TELL survey is administered every two years; therefore, the study identified principals whose scores did not correspond to the current academic school year. This lapse in time could also lead to another limitation, for a principal might be interviewed who has taken a promotion or a new position, and would therefore not currently work at the school that is associated with their TELL scores. Lastly, the TELL survey was replaced in Kentucky with the IMPACT survey in 2019; however, both surveys examine teacher leadership, and the insights gleaned from the principal participants will apply to either survey.

The delimitations of the study rest in its geographical confinement. The four rural and semi-rural districts were intentionally selected because of their affiliation with a regional educational cooperative. The regional educational cooperative provides professional development, resources, and generalized support to all of their partner schools. Specifically, these schools and their leaders have taken part in multiple professional development opportunities through a federal grant where teacher leadership has been addressed.

\section{Organization of the Study}

Chapter one provides the background and purpose of the study, as well as key terms, a brief methodological overview, and limitations and delimitations to the study. Chapter two synthesizes various research on teacher leadership definitions, school-level teacher leadership structures and systems, the role of the administrator in teacher leadership efforts, and administrative beliefs about teacher leadership. Chapter three 
provides a detailed description of the research methodology used to answer the research questions. Chapter four thematically analyzes the study's data and presents its findings. Chapter five summarizes the study, as well as identifies practical implications, provides a researcher's reflection, and makes recommendations for additional research.

\section{Chapter Summary}

Despite over a dozen definitions of teacher leadership existing across numerous studies, there is yet to be a study where principals who have been found to cultivate teacher leadership are interviewed with the goal of obtaining a practitioner-driven definition. Teacher leadership is consistently mentioned as being both a key component of teacher satisfaction and retention, as well as having an impact on student achievement. This study identified principals who cultivate teacher leadership, and through a multiple case study approach, analyzed how administrators define and support teacher leadership, examined what they collectively believe about teacher leadership, and explored the structures they use to promote teacher leadership. 


\section{CHAPTER II}

\section{LITERATURE REVIEW}

\section{Defining Teacher Leadership}

Since as early as 1995 (Darling-Hammond, Bullmaster, \& Cobb), researchers have attempted to define teacher leadership. York-Barr and Duke's (2004) definition of teacher leadership is the most commonly cited one in research on the subject (Angelle \& Schmid, 2007; Greenier \& Whitehead, 2016; Liljenberg, 2016; Smith, Hayes, \& Lyons, 2017; Uribe-Florez, Al-Rawashdeh, \& Morales, 2014; Wenner \& Campbell, 2017); however, more than a dozen other definitions are also used in various studies and publications (Childs-Bowen, Moller, \& Scrivner, 2000; Danielson, 2006; DarlingHammond, Bullmaster, \& Cobb, 1995; Harrison \& Killion, 2007; Helterbran, 2010; Katzenmeyer \& Moller, 2001; Krisko, 2001; Lambert, 2003; Reeves, 2008; Sergiovanni \& Starratt, 1998).

This section serves to examine York-Barr and Duke's definition of teacher leadership, and its lasting legacy, as well as its noted strengths and limitations. From there, fourteen other teacher leadership definitions will be outlined and analyzed, with common themes being noted and examined. Ultimately, the strengths and limitations of these definitions will be discussed. 


\section{Primary Teacher Leadership Definition}

York-Barr and Duke (2004) is still widely viewed as the cornerstone of teacher leadership research and is still heavily utilized in two key areas: its implications for future teacher leadership research, and its definition of teacher leadership. York-Barr and Duke define teacher leadership as "the process by which teachers, individually or collectively, influence their colleagues, principals, and other members of school communities to improve teacher and learning practices with the aim of increased student achievement" (p. 287). This definition has persisted and been heavily utilized in expanded research on the subject (Angelle \& Schmid, 2007; Greenier \& Whitehead, 2016; Liljenberg, 2016; Smith, Hayes, \& Lyons, 2017; Uribe-Florez, Al-Rawashdeh, \& Morales, 2014). Their definition encompasses key areas of teacher leadership that are often studied: teacher power and influence, administrative support, and student achievement.

Despite its wide use in scholarship, York-Barr and Duke's definition of teacher leadership is not without its critics. Some have noted that the definition is too pedagogically centered and does not take into account the constantly evolving leadership demands that exist for teachers outside of a classroom setting (Liljenberg, 2016).

Cosenza (2015) suggests York-Barr and Duke's definition focuses more on collaboration instead of the authority that is vested in one person. In fact, the argument has been made that there can be no one set definition of teacher leadership because of the contextual nature of teaching itself (Neumerski, 2013).

York-Barr and Duke's implications for future teacher leadership research provide a roadmap for future studies. Their implications are presented as a series of eight questions, with three of these questions specifically highlighting the role of the 
administrator in shaping teacher leadership efforts: "How might leadership by teachers be differentiated to address the numerous and varied formal and informal types of leadership work that is assumed by teachers?" "How can the work of teacher leaders be structured to maximize positive effects on teaching and learning, addressing such issues as maintaining a clear focus on instructional improvement and providing opportunities for job-embedded collegial work?" and "In what was are principals influenced and supported in their roles as instructional leaders through collaboration with teachers?" (292). These three questions all point to future research that focuses on the structures and supports for teacher leadership in schools, which in turn connects to how administrators work with teachers to cultivate and grow these efforts.

\section{Alternate Teacher Leadership Definitions}

While York-Barr and Duke's definition is the most pervasive across teacher leadership research, there are over a dozen other definitions that emerge across various studies (Table 1). These alternate definitions range in both their length and approach to teacher leadership. Despite their differences, these teacher leadership definitions gravitate around four key elements: teacher influence, teacher empowerment, teacher practice, and student achievement.

Teacher leadership definitions highlight the need for teacher influence in decision making efforts both in the classroom, as well as outside of it (Crowther et al., 2002; Danielson, 2006; Harrison \& Killion, 2007; Katzenmeyer \& Moller, 2011; Murphy, 2005; Reeves, 2008). This influence includes students (Katzenmeyer \& Moller, 2011) and fellow teachers (Harrison \& Killion, 2007; Murphy, 2008; Reeves, 2008). Teacher influence can even include a school's community (Crowther et al., 2002; Danielson, 
2006; Katzenmeyer \& Moller, 2011). Teacher influence is one of the areas where other teacher leadership definitions align with York-Barr and Duke's take on the subject, helping to drive home a critical component of teacher leadership: A school staff that believes it has influence to make large, impactful decisions will make great strides with student achievement.

Teacher influence cannot happen without teachers being empowered, which is reflected in multiple teacher leadership definitions (Childs-Bowen, Moller, \& Scrivner, 2000; Danielson, 2006; Helterbran, 2010; Lambert, 2003). Teachers empowerment can occur when a teacher contributes to school improvement (Childs-Bowen, Moller, \& Scrivner, 2000), and results from a teacher being informed (Danielson, 2006).

Empowered teachers also have a sense of confidence (Helterbran, 2010), and know themselves well enough as to not be intimidated into silence by administrators, central office staff, or leaders with positional authority (Lambert, 2003). Ultimately, when teachers are empowered, student achievement will be positively impacted. John Hattie (2015) notes that collective teacher efficacy, or the belief among teachers that they have the ability to positively affect students, is the number one area out of 272 identified influences that positively impacts student achievement $(p=1.62, N=195)$. If teachers believe that they have the power to influence their students, they will do it.

Teacher leadership definitions almost universally center around two fundamental elements: strengthening teacher practice, and enhancing student learning and achievement (Childs-Bowen, Moller, \& Scrivner, 2000; Danielson, 2006; DarlingHammond, Bullmaster, \& Cobb, 1995; Harrison \& Killion, 2007; Helterbran, 2010; Katzenmeyer \& Moller, 2001; Krisko, 2001; Lambert, 2003; Reeves, 2008; Sergiovanni 
$\&$ Starratt, 1998). Teacher leaders are best when they are able to help each other. When educators' pedagogical practice is strengthened, students ultimately benefit through having a richer educational experience.

\section{Table 1}

Definitions of teacher leadership

\section{Definition}

Teachers become leaders when they function efficiently in professional learning communities to impact student learning, contribute to school improvement, inspire excellence in practice, and empower stakeholders to participate in educational improvement. (p. 28)
Source

Childs-Bowen, Moller, \& Scrivner (2000)
Teacher leadership facilitates principled action to foster wholeschool success. Teacher leaders transform teaching and learning and tie the school and community together, and advance the community's social mission and quality of life. (p. 10)
Crowther et al. (2002)
Teacher leadership is inextricably connected to teacher learning; that teacher leadership can be embedded in tasks and roles that do not create artificial, imposed, formal hierarchies and positionsand that such approaches may lead to greater professionwide leadership as the "normal" role of teacher is expanded; and that the stimulation of such leadership and learning is likely to improve the capacity of schools to respond to the needs of students (p. 89)
DarlingHammond, Bullmaster, \& Cobb (1995)
Teachers exhibit leadership in multiple, sometimes overlapping, ways. Some leadership roles are formal with designated responsibilities. Other more informal roles emerge as teachers interact with their peers. The variety of roles ensures that teachers can find ways to lead that fit their talents and interests. Regardless of the roles they assume, teacher leaders shape the culture of their schools, improve student learning, and influence practice among their peers. (p. 77)
Harrison \&

Killion (2007) 


\section{Table 1 Continued}

Definitions of teacher leadership

Definition

Source

It is imperative for teachers, individually and collectively, to

Helterbran (2008) consider what they can do to ensure that they are practicing the art and craft of teaching in a manner that is of service to children's achievement and society. (p. 126)

Teacher leadership, in its truest sense, involves those informal

Helterbran (2010) aspects of leadership, where a teacher sees a need or identifies a problem and takes the reins to address it within his or her means... this "emergence" cannot and will not occur unless and until teachers recognize their own leadership potential and develop the confidence and skills to be effective teacher leaders. In doing so, teachers will come to realize that taking responsibility for their own professional learning and collaborating meaningfully with and among colleagues not only impacts their personal effectiveness in a school, but can produce results in the classroom nothing short of miraculous. (p. 365)

Teacher leaders lead within and beyond the classroom; identify with and contribute to a community of teacher learners and Katzenmeyer \& leaders; influence others toward improved educational practice; Moller (2001) and accept responsibility for achieving the outcomes of their leadership (p. 6)

Teacher leadership is a step beyond the traditional teacher role.

Krisko (2001)

Teachers are potential leaders who can be instrumental in initiating and implementing a major paradigm shift from a traditional school to an effective learning community. Teachers must be encouraged to take the initiative to change the traditional trend, to get involved in professional conversations, to accept the responsibility for student learning, and to work toward a common goal as a teacher, learner, and leader. (p. 6) 


\section{Table 1 Continued}

Definitions of teacher leadership

Definition

Source

A teacher leader may be seen as a person in whom the dream of

Lambert (2003) making a difference has been kept alive, or has been reawakened by engaging colleagues and a professional culture. Those who have managed to keep their sense of purpose alive and well are reflective, inquisitive, focused on improving their craft, action oriented; they accept responsibility for student learning and have a strong sense of self. That is, they know themselves and their intentions enough so that they are not intimidated into silence by others. They are open to learning and understand the major dimensions of learning in schools: the learning of students, learning of colleagues, learning of self, learning of the community. Those who are reawakened to their sense of purpose may find this path within an improving school, or in a setting outside the school, such as a network, university programme, or thoughtfully designed initiatives such as the National Board Certification process or the National Writing Project. When the source of reawakening is outside the school, these individuals may not be able to stay long in their own schools if those schools are incongruent with their renewed feelings and thinking about themselves and their mission as teachers. (p. 422)

The act of influencing the classroom practices of professional

Reeves (2008) educators

Teacher leadership involves the experimentation and examination Sergiovanni \& of more powerful learning activities with and for students, in the Starratt (1998) service of enhanced student productions and performances of knowledge and understanding. Based on this leadership with and of students, teacher leaders invite other teachers to similar engagements with students in the learning process. (p. 149)

Teacher leadership moves beyond those... leadership opportunities that are apart from teachers' classroom work to Silva, Gimbert, \& include opportunities for leadership to be a part of teachers' dayNolan (2000) to-day work. (p. 781) 
Table 1 Continued

Definitions of teacher leadership

Definition

Source

Teacher leadership is the process by which teachers, individually or collectively, influence their colleagues, principals, and other members of school communities to improve teacher and learning

York-Barr \&

Duke (2004) practices with the aim of increased student achievement (p. 287)

\section{Strengths and Limitations}

As a whole, the multiple examples of teacher leadership definitions provide both researchers and practitioners a number of strengths that can be applied to both research and practice. The fact that nearly every definition highlights the interconnectedness between teacher leadership and student achievement serves as a means of making leadership efforts tangible to those who engage in it. The more empowered a staff is, the more impact they will have on student achievement (Angelle \& Teague, 2014; Cook, 2014; Danielson, 2006; Hattie, 2015). This work should be constantly grounded around student needs.

The fact that multiple definitions also emphasize the need for teacher influence, both at the school and community levels, should serve to bolster teacher and administrative desire to pursue teacher leadership efforts. Again, this will feed into student achievement, for the power and influence teachers have in their schools and community will serve to empower the students in their classrooms (Danielson, 2006; Quaglia \& Corso, 2014; Quaglia \& Lande, 2017).

One of the largest limitations of the multiple definitions of teacher leadership is the sheer number of definitions that exist. An argument for multiple definitions of 
teacher leadership is that a researcher or school leader can choose one that is best contextualized in their work (Wenner \& Campbell, 2017); however, these varying definitions will only lead to more confusion and less coherence in future research and practitioner efforts to streamline what truly works when establishing school beliefs and structures around teacher leadership. A universally accepted definition of teacher leadership would help to focus teacher leadership research around a common viewpoint.

\section{Role of the Administrator in Teacher Leadership Efforts}

Building upon the implications for future research of York-Barr and Duke, research on teacher leadership has become more focused on the role of the administrator in creating and cultivating teacher leadership efforts among a school's staff. This research on how principals play a role in teacher leadership can be divided into two areas: the culture and climate principals create, and the structures and systems principals implement. The formal structures and systems in place to support teacher leadership can stem from a school, district, or state's involvement with a building's leadership.

\section{Climate and Culture}

The culture and climate a principal creates has an impact not only on student achievement, but also the teacher leadership efforts in a school (Carpenter, 2015; Deal \& Peterson, 2009). In fact, the revolutionary, and highly cited, work of John Hattie lists collective teacher efficacy as the highest factor influencing student achievement (2015), which stems directly from principals shaping a building's culture and climate. Principals who focus their efforts on transformative leadership, and focus their school culture around collaboration, can impact teacher leadership efforts by providing their staff with a balanced, connected leadership lens (Drago-Severson, 2009). 
An additional benefit of a principal's focus on culture and climate is the sense of trust and security it creates among staff, which in turn gives teachers the ability to take risks in leadership efforts (Brezicha, Bergmark, \& Mitra, 2015; Minckler, 2014; Williams \& Johnson, 2013). Brezicha, Bergmark, and Mitra (2015) used case descriptions to suggest that principals who understand individual teachers' views and philosophies increase both school culture and teacher efficacy. Similarly, Minckler (2014) examined the relationship between school leadership development and sustaining teacher social capital and found that an emphasis on school culture that is built upon trust should result in teacher candidate quality, job satisfaction, and increased student achievement. A culture of collaboration through shared beliefs, values, and a unified vision and mission is so important that it is seen as the foundation of sustainable leadership (Cook, 2012). Williams and Johnson (2013), through administering a survey to thirty school administration candidates, found that strategic leadership planning has to incorporate teachers in order to fully empower a school's staff. A positive and supportive school culture is so powerful that, when absent, it can hinder collaborative learning and teacher leadership efforts (Neumerski, 2012).

By focusing on a culture of collective empowerment and teacher and student voice, teacher leadership efforts are more likely to flourish (Quaglia \& Lande, 2017). Helterbran's (2010) examination of teacher leadership literature on the subject suggests that there is no larger influence on a school's culture of fun, high expectations, and empowerment than a school's leadership team. The culture of collective leadership and voice that school administrators cultivate ultimately trickles down to students and has the potential to transform student learning (Quaglia \& Corso, 2014). Ultimately, a leader 
who has an intentional and systemic approach to a school culture that empowers all stakeholders has structures in place that will mirror and support these shared cultures.

\section{Structures and Systems}

Just as there are a multiple definitions of teacher leadership, there are many different structures a school's leadership team can enact in order to promote teacher leadership efforts. Many of these structures are formal, from school-specific leadership roles like a department chair or involvement in a school-based decision-making council; however, these structures and roles can develop informally based on the reconfiguration of power dynamics within a school. This section serves to examine the school structures and systems, both formal and informal, that influence and support teacher leadership.

Building structures and systems that support collaboration among staff and promote teacher leadership efforts stem from a culture and climate that value leadership and collaboration. Sinden, Hoy, and Sweetland (2004) suggest that school organizational structures fall under two categories: formalization (the extent to which the organization has a codified set of rules, regulations, procedures, and policies), and centralization (the degree to which employees participate in decision making). Their work views these two structures as independent factors of school organization that co-exist in every building, with some schools adhering to "enabling structures," while others focusing on "hindering structures."

The characteristics of enabling centralization structures in schools emphasize problem solving, cooperation, collaboration, and change, whereas schools that adhere to hindering centralization structures promote conformity, control, obedience, and maintaining the status quo. Similarly, schools that have enabling formalization structures 
promote dialogue among staff, flexibility, judgment, and guidance, whereas schools that have hindering formalization structures promote conformity, rigidity, obedience, and punishment (199). By administrators ensuring their school structures-both centralized and formalized - are enabling, building leaders can put tangible and specific practices in place to empower their teachers.

\section{School-Specific Roles}

There are multiple examples of formal, school-specific structures that promote teacher decision making and participation in the body of teacher leadership research. Professional learning communities, also known as PLCs, are one of the most widely mentioned of these examples (DuFour, 2004; Scribner, Sawyer, Watson, \& Myers, 2007; Vanblaere \& Devos, 2016). Much like the definition of teacher leadership, identifying universal characteristics of professional learning communities is a nebulous, seemingly unsurmountable feat. DuFour (2004) identifies three "big ideas" that all successful PLCs should structure themselves around: ensuring that students learn, maintaining a culture of collaboration, and a focus on results.

Others have noted that professional learning communities should focus on problem-finding discussions on student achievement, where teachers discuss issues as diverse as student retention to lesson and unit planning (Scribner, Sawyer, Watson, \& Myers, 2007). Vanblaere and Devos (2016) note that PLCs should have three tenets as well, which serve as a semiformal update to DuFour's work. They note that all PLCs should have collective responsibility, deprivatized practice—or an open classroom concept where teachers can observe and learn from one another-and reflective dialogue. Despite the varying characteristics and focuses of professional learning community in the 
body research, one constant emerges: administrators are the linchpin of a successful PLC (DuFour, 2004; Scribner, Sawyer, Watson, \& Myers, 2007; Vanblaere \& Devos, 2016). Through administrative support in PLCs, teachers are empowered to own their instructional practice, and can therefore make strides towards increasing student achievement.

Another school-specific structure that encourages teacher leadership is a clearly defined leadership role for teachers within a school or district. Again, like so many of the findings in the area of teacher leadership, there are many ways that this can manifest itself in schools. Teacher leadership roles can be clearly defined, principal-delegated positions like chairing committees or starting new initiatives (Cheng \& Szeto, 2016; Cook, 2014). These roles can also be content-centric positions that serve as liaisons between teachers and administrators (Smith, Hayes, \& Lyons, 2017). In other instances, teacher leadership roles can be teacher-initiated and more loosely defined. Teachers who have the support of their administrative staff and feel that their values align with those of their administration and colleagues often feel as if they have freedom to try new initiatives without a clearly defined role being necessary (Angelle \& Schmid, 2007; Angelle \& Teague, 2014; Cheng \& Szeto, 2016). Danielson (2006) argues that the principal characteristic of teacher leadership is its informality, and that teachers earn leadership through work with their students and colleagues, and not through an assigned role. Regardless of the range of what teacher leadership roles look like, administrative support in fostering it in their schools is central to its success (Angelle \& Teague, 2014; Cook, 2014; Danielson, 2006). 


\section{Teacherpreneurs}

A recent example of a more formalized teacher leadership role is what is being called a teacherpreneur. Berry (2015) defines teacherpreneurs as follows:

Teacherpreneurs are classroom experts who teach students regularly but also have time, space, and reward to spread their ideas and practices to colleagues as well as administrators, policy makers, parents, and community leaders. Without leaving the classroom, they will serve as virtual coaches, curriculum publishers and curators, student assignment analysts, edugame inventors, community organizers, policy researchers, and creators of their own schools. (p. 147)

Organizations like the Center for Teaching Quality have been instrumental in working with state-level partners to improve schools through developing collective leadership and establishing leadership roles, like teacherpreneurs, in schools and districts (Center for Teaching Quality, 2018).

In Kentucky, the teacherpreneur role has received formal, state-level support through organizations like the Kentucky Network to Transform Teaching. This network, working in collaboration with the Kentucky Department of Education, developed the Kentucky Teacher Leadership Framework (Kentucky Department of Education, 2015). The framework outlines six key areas in which teachers can lead: from the classroom, through modeling and coaching, in groups and teams, to increase teacher voice and influence, to professionalize teaching, and to connect to a larger community and world. By supporting the work of this document, the Kentucky Department of Education has taken a systemic approach towards developing teacher leadership across the state. In 
order for any position like this to be effective; however, a school's principal and administrative staff will need to be supportive of these efforts.

Teacherpreneurs can exist within a school in several contexts and can be called different names. Some schools use instructional coaches, or goal clarity coaches, in this type of part-time teacher, part-time instructional expert role. Instructional coaches often work with administrators to define their roles and can serve to build trust with teachers while supporting both administrative efforts and teacher leadership, all while still teaching part time each day (Walkowiak, 2016). Whatever title they go by, these hybrid teacher roles need to be given the time and support to balance both roles. They are often spread too thin, and are given multiple, conflicting initiatives to develop. By balancing multiple indicatives and expectations from fellow teachers, administrators, and state policy makers, teacherpreneurs run the risk of becoming more of a manager, and less of an agent of advocacy and change for fellow teachers (Kane \& Rosenquist, 2018).

\section{School-Based Decision-Making Councils}

Beyond the Kentucky Teacher Leadership Framework, a long-standing structure that exists at almost every school across the state is a School-Based Decision-Making Council, or SBDM. SBDM councils have seen success when it comes to including teachers in school decision making. The types of decisions that SBDM councils make can be broken down into thirteen categories, ranging from determination of curriculum and staffing allocations to budgetary decisions and staff professional development (Klecker, Austin, \& Burns, 2000). Given the wide array of what teachers and community members can contribute to, their influence on a school can be far reaching through their 
involvement on an SBDM council. SBDM ultimately is a built-in system that ensures teachers constantly have a say in large school decisions (David, 1994).

Despite their long-standing persistence in Kentucky schools, SBDM councils are not without their flaws. Schools across the state differ greatly in the types of decisions they make, and often operate with little to no oversight from state stakeholders (Klecker, Austin, \& Burns, 2000). Furthermore, school councils do not meet on a regular basisespecially during summer months — and as much as $97 \%$ of parents, $90 \%$ of teachers, and $55 \%$ of principals serving on SBDM councils have three or fewer years of experience. This can result in similar decisions being made for schools each year, as members are in a constant state of transition and often don't have the ability to review previous SBDM decisions, and in turn can stall the school improvement process (Klecker, Austin, \& Burns, 2000). Other barriers also exist, like recruiting parents to serve on councils, and the fact that classified employees - those who serve in positions like instructional assistants or work in a school's cafeteria or front office - do not have a representative who can make decisions on their behalf. Only certified staff members can serve on SBDM councils (David, 1994). These significant issues can limit a teacher's, and an SBDM council's, ability to operate with consistency and can dilute their impact on student and school success. It is ultimately up to the principal to ensure that this structure is run in a way to maximize the influence and contribution of teachers and community members.

All of the aforementioned research on the role of the administrator in cultivating teacher leadership can be synthesized into one, easy-to-understand concept: intent to build teacher capacity. Administrators must be intentional in how they cultivate 
relationships with teachers, how they shape and support school culture, and how they design and implement building structures and systems that enable and empower teachers. Administrators who intentionally focus on efforts to improve teacher leadership, beyond valuing both teachers and instruction, also share a set of leadership qualities that allow them to be more intentional and effective with their approaches to building management.

\section{Leadership Qualities of Teacher-Focused Administrators}

Within the body of research, a sketch of the leadership qualities of principals who cultivate teacher leadership efforts emerges. Principals who enable teacher leadership are often seen as collegial (Sinden, Hoy, \& Sweetland, 2004), supportive (Danielson, 2006; York-Barr \& Duke, 2004), and trustworthy (Sebastian, Allensworth, \& Huang, 2016; Vanblaere \& Devos, 2016). Furthermore, these principals believe in the power of mentorship (Augustine-Shaw \& Funk, 2013; Clayton, Sanzo, \& Myran, 2012; Daresh, 2004; Grissom, 2011)

Sinden, Hoy, and Sweetland (2004) notes that a collegial principal is one who "treats teachers as colleagues, is open, change-oriented, egalitarian, and friendly, but at the same time sets clear expectations and standards of performance" (p. 200). Principals who use a collegial leadership approach are likely to create a perception of a school that is open, helpful, and empowering (Sinden, Hoy, \& Sweetland, 2004). These principals are seen as leaders who can enliven their teaching staff with passion and enthusiasm (Sinden, Hoy, \& Sweetland, 2004).

Being supportive as a building leader is a necessary leadership quality to possess in order to promote teacher leadership (York-Barr \& Duke, 2004). Danielson (2006) also 
identifies being supportive as the leadership quality that has the most impact on promoting teacher leadership. She clarifies that administrative support stems from supporting teachers when they want to try a new initiative, garnering the support of central office administration to coordinate projects teachers are passionate about, offering vocal public support to enhance morale and a culture of empowerment, and even giving fiscal support so teachers can pursue professional development or can obtain the resources necessary for innovative instructional practices.

Garnering the trust of teachers is critical for a principal who wants to cultivate teacher leadership (Sebastian, Allensworth, \& Huang, 2016; Vanblaere \& Devos, 2016; York-Barr \& Duke, 2004). The concept of teacher-principal trust is necessary when establishing a culture of teacher empowerment (Sebastian, Allensworth, \& Huang, 2016). Both collegiality and supportiveness stem from the support and trust teachers feel towards their administrative staff and connect to the power administrators have to motivate their staff (Danielson, 2006; Vanblaere \& Devos, 2016). This quality of trust has a trickle-down effect, which also connects to the trust that students have towards teachers, and that parents have towards a school (Sebastian, Huang, \& Allensworth, 2017).

Principals who retain and support teachers believe in and have received strong administrative mentorship (Augustine-Shaw \& Funk, 2013; Grissom, 2011). Having a teacher-focused leadership mindset can result from either on-the-job mentorship and socialization from a direct supervisor or colleague (Bush, 2018; DeHann \& Burger, 2005), or from participation in a specific mentorship program (Augustine-Shaw \& Funk, 2013; Clayton, Sanzo, \& Myran, 2012; Daresh, 2004). Principal mentorship has been 
found to be beneficial both novice and veteran principals (Alsbur \& Hackman, 2006). Regardless of where or how principals receive their mentorship, administrators who maintain healthy mentoring relationship with a mentee can have a positive impact both on teachers (Brown, 2003; Corcoran, Schwartz, \& Weinstein, 2012; Ingersoll \& Strong, 2011) as well as students (Clayton, Sanzo, \& Myran, 2012; Corcoran, Schwartz, \& Weinstein, 2012; Donomoyer, Yennie-Donomoyer, \& Galloway, 2012; Manna, 2015).

The four administrative leadership qualities examined — collegiality, supportiveness, trustworthiness, and belief in mentorship — may seem like obvious traits a principal would need in cultivating teacher leadership efforts; however, with the demands and rigorous pace of the school day, leaders have very little time to reflect upon issues like their perceived leadership qualities. Furthermore, the research on administrative leadership qualities fails to address the authenticity of the leaders in question.

\section{Transformational Leadership in Educational Settings}

Transformational Leadership is a theoretical framework that emerges in both teacher leadership research and as a philosophical guide for many educational professionals. Burns (1978) introduced the theory of transformational leadership by noting the following:

The transforming leader recognizes and exploits an existing need or demand of a potential follower. But, beyond that, the transforming leader looks for potential motives in followers, seeks to satisfy higher needs, and engages the full person of the follower. The result of transforming leadership is a relationship of mutual stimulation and elevation that converts followers into leaders and may convert leaders into moral agents. (p. 4) 
Many scholars have taken Burns' initial work on transformational leadership theory and synthesized it into actionable steps. Most notably, Kouzes and Posner (2012) provide five essential practices of transformational leaders: model the way through clarifying values and setting an example, inspire a shared vision through enlisting others, challenge the process through searching for opportunities and taking risks, enable others to act through fostering collaboration and strengthening others, and encourage the heart through recognizing contributions and celebrating the values and victories.

Transformational leadership theory — with its focus on empowerment, satisfaction, and growth of leaders from within — has multiple administrative and schoollevel applications. Jantzi and Leithwood (1996) suggest that transformational leadership is well suited for the challenges educational leaders face, especially in a world of everchanging expectations and where fostering the growth of teachers is a necessity. Through their work, Jantzi and Leithwood developed six dimensions of transformational school leadership practice, with the aim of applying Burns' transformational leadership theory to a school setting: identifying and articulating a vision, fostering the acceptance of group goals, providing individualized support, intellectual stimulation, providing an appropriate model, and high-performance expectations.

Transformational leadership is a theoretical model that is still desperately needed in the world of education. In fact, the theory has gone largely untested in school systems due to their pervasive hierarchical nature, where only a few, selected teachers and administrators are given any semblance of control and influence (Lindahl, 2008). When school-level leaders do utilize the tenets of transformational leadership theory; however, both student achievement and teacher empowerment benefit (Valentine \& Prater, 2011). 


\section{Summary of Literature Review Findings}

Teacher leadership research, while growing more thorough in its scope, has inadequately identified the conscious steps that successful building-level leaders have taken to establish and sustain teacher leadership efforts. The juxtaposition between the structures that are used to support teacher leadership and the roles that teacher leaders can take on in a school, creates room for further investigation. Furthermore, no study has identified school leaders who have been successful in cultivating teacher leadership, as identified by their teachers, and has looked for common themes in their approaches to school structure and their beliefs about teacher leadership. Likewise, while studies have focused on the leadership qualities of administrators who foster teacher leadership, there is little evidence of a study exploring what these principals believe about teacher leadership, as well as how they define the concept of teacher leadership.

While case studies and literature reviews are two of the primary methodologies used in teacher leadership studies, there are very few phenomenological studies on teacher leadership (Raffanti, 2008), and none where administrative perspectives on teacher leadership are examined. Phenomenology; therefore, will be the methodology of this study. By examining the study's research questions, research design, and methodology, it is the hope that teachers and teacher leaders can bridge the oftencontentious schism between theory and practice. 


\section{CHAPTER III \\ METHODOLOGY}

\section{Introduction}

The purpose of this study was to examine how principals define, cultivate, and intentionally shape teacher leadership by answering these four research questions:

Q1. How do administrators define teacher leadership?

Q2. What shared beliefs about teacher leadership exist among administrators who cultivate it?

Q3. What challenges emerge when creating teacher leadership opportunities?

Q4. How do administrators consciously cultivate teacher leadership?

In order to answer these questions, a qualitative, phenomenological design was conducted, using Burns' (1978) Transformational Leadership Theory as a guiding theoretical framework. The study's sample consisted twelve principals who were selected through the 2017 TELL (Teaching, Empowering, Leading, and Learning) Survey. The data collected from the interviews was thematically coded through inductive and deductive means and was analyzed. 


\section{Research Methodology}

A phenomenological design was qualitative methodology used to conduct this study. Phenomenology was the most effective means for answering the study's research questions since it is based on a methodological approach that "describes the common meaning for several individuals of their lived experiences of a concept or phenomenon." (Creswell \& Poth, 2017, p. 75). Bourke (2007) expands upon the value of this methodology by emphasizing that phenomenology is "the interpretive study of human experience in which phenomena are examined and clarified through the human situations" (p. 12).

Phenomenology is a methodological approach that reduces "individual experiences with a phenomenon to a description of a universal essence" (Creswell \& Poth, 2017, p. 75), and is therefore an appropriate methodology for exploring the shared strategies and beliefs among administrators who successfully cultivate teacher leadership efforts among their staff. Cocek (2012) goes further by describing how phenomenology allows researchers to "take a closer look into the corners and moments that occur in education that we so often take for granted" (p. 95). Focusing on multiple administrators who have been recognized for cultivating and promoting teacher leadership allowed for the gaps in teacher leadership research to be addressed by examining what these principals did to create teacher leadership and what they believe about the concept. Also, by phenomenologically examining school administrators who have fostered teacher leadership, a more complete perspective emerged on exactly how administrators cultivate teacher leadership and examined their beliefs on the phenomenon of teacher leadership are. 
Narrative inquiry could have been used as a methodological approach; however, designing the study up in this way would have focused more on the story behind administrators' efforts in creating teacher leadership instead of focusing on the common thematic elements that emerge from studying multiple cases of administrators who foster teacher leadership (Creswell \& Poth, 2017). Ethnography could have also been used to frame the study, but research of this nature would be best carried out by a researcher embedding themselves in a school with a clear teacher leadership-focused administrator for an extended period of time. A phenomenological approach allowed me to speak with more participants across multiple schools and school settings, which would not have been possible with an ethnography (Creswell \& Poth, 2017).

A single case study approach could also have been used to facilitate this research; however, this method has its limitations. Single case designs center more around a single experience, and often focus on a lone, extreme or unique case (Yin, 2013). Another pitfall of single case study design is that it has the potential to "shift, unbeknownst to the researcher, during the course of the study" (Yin, 2013, p. 42). Phenomenological design lets themes emerge from the subjects themselves, and a unknowing shift within the nature of the findings will therefore be negated (Creswell \& Poth, 2017).

\section{Research Design and Sources of Data}

Following the phenomenology research procedures established by Creswell and Poth (2017), the first set in this study was to select twelve principals—-four Elementary, four Middle, and four High School—who were identified as establishing a sense of teacher leadership among their staff. In order to identify these administrators, the results 
from the 2017 TELL (Teaching, Empowering, Leading, and Learning) Survey were examined.

The TELL Survey was an anonymous, Likert-scale assessment given to every teacher in the state of Kentucky on a two-year basis. In 2017, over 41,500 educators (or 91\% of teachers in the state) responded to the survey (TELL Kentucky, 2020). The survey included questions on nine topics: Community Engagement and Support, Teacher Leadership, School Leadership, Managing Student Conduct, Use of Time, Professional Development, Facilities and Resources, Instructional Practices and Support, and New Teacher Support. On the Teacher Leadership portion of the survey, Kentucky teachers were asked 18 questions that examine issues from if teachers are recognized as instructional experts and if teachers have an appropriate level of influence on decision making, to if teachers in a school have a role in selecting new teachers and instructional materials and resources.

In order to identify administrators for the study, the TELL Survey results from 63 schools spanning across six school districts were initially analyzed. These districts were selected based on their close proximity to one another, coupled with their collective involvement in a regional educational cooperative. In order to select principal participants, I identified schools with highest responses of "Agree" and "Strongly Agree" on the 18 teacher leadership questions contained within the survey. A list of potential participants from all levels, Elementary, Middle, and High, were targeted, and twelve principals were ultimately selected, with four principals from each level participating in the interview. 
Whereas larger school districts have formal mechanisms for vetting and working with researchers, rural schools often don't have either a formal IRB system, or aren't often asked to take place in research studies. Therefore, once the schools and leaders were identified, participants were contacted directly via email to ask for their participation in the study. From the list of respondents, twelve principals were selected to interview using purposeful sampling, with the goal of identifying administrators who were diverse in regard to gender, race, and experience level.

Nine open-ended research questions were used to elicit responses about the participants' beliefs towards teacher leadership, as well as the ways they consciously cultivate it (See Appendix A for the interview questions used). An interview protocol was established before conducting the twelve formal interviews for the study. Once this protocol was established, a pilot interview was conducted before the formal interviews occurred. Creswell and Poth (2017) suggest that researchers conduct pilot interviews in order to refine their plans to collect data, as well as to strengthen the questions asked. After the pilot interview took place, the interview questions and interview protocol were refined before the formal interview conversations took place.

Each school administrator, which will be defined as the head principal of the school during the TELL survey cycle, sat down for one, 45-to-60-minute interview. The interview subjects were provided with the interview protocol in advance, which included the questions that were asked during the session. The interviews took place at the participants' school or current place of employment, as the interviewee should feel comfortable during the session (Creswell \& Poth, 2017). Probing questions were used to further engage the participants as necessary. During the interview, an interview protocol 
tool was used to collect direct quotes, as well as my supplemental notes, reflections, and observations.

\section{Sample}

The initial sample of interest spanned six counties and 63 potential schools. This geographical region was selected because of the school districts' proximity to one another, as well as because of their affiliation with a regional educational cooperative. The regional educational cooperative provides professional development, resources, and generalized support to all of their partner schools. Specifically, these schools and their leaders have taken part in multiple professional development opportunities through a federal grant where teacher leadership has been addressed, with monthly meetings being held on various leadership topics, ranging from hiring practices to academic initiatives. Furthermore, these partner schools were familiar with working with outside agencies and researchers and were therefore be willing to work with the study.

Given the fact that the research questions were about administrators' beliefs about and shaping of teacher leadership in their building, and since multiple school administrators at every level of school were interviewed, a sample size of twelve interviewees elicited enough information to make an informed study. Purposeful sampling was used to select participants that were diverse in regard to gender, race, and years of experience.

\section{Ethics}

The sample selected adhered to a strict ethical sampling design. Onwuegbuzie and Collins (2007) outline six tenets of ethical sampling, which include guidelines pertaining to guaranteeing confidentiality, as well as being mindful of gender, cultural, 
and religious differences. Given the fact that much of the data collected could be used to publicly identify either schools or participants, additional measures were taken to further protect confidentiality. The school names, as well as the names of the participants, have been changed, and specific TELL survey data and results are not explicitly stated in order to make the participants less identifiable. Since twelve administrators were interviewed, additional opportunities for anonymity were provided due to the larger sample size.

\section{Data Collection}

The interviews were digitally recorded on two separate recording instruments to ensure the conversation is captured. The study's participants were informed of the conversation being recorded before the interviews occurred, and an informed consent document was reviewed and signed by each participant before formally beginning our conversations. The interviews, once recorded, were transcribed via the Rev.com transcription service. Additional pieces of data that were collected during the interviews that participants willing shared, such as committee guidance documents, flow charts, and building-level pieces of communication, were analyzed along with the survey results.

The collected data was analyzed using the Dedoose coding software as a qualitative data management system. Deductive coding took place based on the characteristics of transformational leadership as identified by Burns (1978). When coding, close consideration was given to identifying terms or phrases that correlate to transformational leadership, such as "empowerment," "growth," "fulfillment," and "vision." Inductive coding procedures were also be utilized, with descriptive coding and process coding being used to analyze the data even further (Miles, Huberman, \& Saldana, 2014). The synthesized data is collected and reported in Chapter 4, and is described and 
analyzed by theme, with particular emphasis being placed on using participants' voices throughout the descriptions. Applications for current practice and recommendations for further research is outlined in Chapter 5.

\section{Conclusion}

This was phenomenological designed study where twelve principals were identified via the 2017 TELL Survey and were interviewed using a set of semi-structured interview questions. Data was collected and was both deductively coded based upon tenets of Transformational Leadership, as well as inductively coded. By focusing on practitioners who have objectively been identified as cultivators of teacher leadership, I am hopeful that a more cohesive, streamlined definition of teacher leadership emerged, and that the data's reported themes - which can also be viewed as a list of tangible strategies for creating teacher leadership opportunities—can be utilized for both future research and for current practitioners. 


\section{CHAPTER IV}

\section{FINDINGS AND ANALYSIS OF DATA}

\section{Introduction}

"It would give me a lot of enjoyment to say that I've cultivated people to grow, because that's my job. My job is to build capacity. My job is to build opportunities. My

job is to, obviously, educate students, but also to create an atmosphere where people feel like they are valued." This quote, which stemmed from my discussion with Heath, perfectly captures the disposition of all of the principals who participated in this study. The analysis of the data in this chapter, which is organized around the study's four research questions found below, all stemmed from interviewing twelve selfless, visionary, empathetic, and inclusive principals.

Q1. How do administrators define teacher leadership?

Q2. What shared beliefs about teacher leadership exist among administrators who cultivate it?

Q3. What challenges emerge when creating teacher leadership opportunities?

Q4. How do administrators consciously cultivate teacher leadership 
This study used a qualitative, phenomenological design. Semi-structured interviews were conducted with twelve principals — four elementary, four middle, and four high school— who were selected through earning high marks on the teacher leadership portion of the 2017 TELL (Teaching, Empowering, Leading, and Learning) Survey. The interviews were inductively and deductively coded through the Dedoose software program, and themes and categories were created that align with the study's research questions.

\section{Participant Profiles}

The twelve principals who participated in this study come from a range of backgrounds and experience levels. Each principal, who has been assigned a pseudonym to protect their confidentiality, provided unique perspectives on leadership, teaching, instruction, and building-level structures in order to inform this study. The following profiles give a description of each participant. References to the names of their schools, as well as their school's level (Elementary, Middle, and High School) have been removed.

\section{Anna}

In total, Anna has over twenty years of educational experience. When describing her views on teacher leadership, Anna described the constant need for educational leaders to remember their roots:

The big word I'm going to tell you right now is empathy, and don't forget where you came from, because I'm always a teacher. When I make decisions for students, I can't forget to put myself back in the role of a teacher. 


\section{Barrett}

Barrett is a veteran administrator, having served as a principal for over thirty years. When describing his transition from the classroom to a leadership role, Barrett joked:

I was too young and too stupid. I was the youngest principal that was hired [in district history]. Still am, still was. And, you know, I told [one of my mentors],

"You need to come over and have lunch one day once I get my school." She says, "No I'm not." I said, "Well, why?" She said, "Because you'll be in the cafeteria every day at lunch just like I am." She said, "You don't need to eat lunch, you'll learn more in the cafeteria than you'll ever learned anywhere else. And to this day, Adam, I try to be there every single day, and I don't eat lunch. I take that time to be present and to I learn more about the kids.

\section{Charlotte}

Charlotte has been in the field of education for over twenty years and taught for almost a decade before leaving the classroom. Charlotte was born and raised in the community in which she serves as a principal:

I am a product of [my current school system]. I went to college on an academic scholarship by way of [a local program]. After college, I came back home. It was important for me to come back home to work having been a product of this school system and not seeing many people that looked like me, because the people that did look like me played a pivotal role in my education. 


\section{Danielle}

Danielle has been a principal for almost two decades. When describing her background, Danielle addressed the role her parents played in shaping many of the issues she would encounter in her professional career:

My mother was a teacher who went on to be an assistant principal, and my dad was a social worker who went on to be a regional director for the department of juvenile justice. So, you know, dinner conversations were interesting from the point of my mom's saying, "Well, I have to suspend them out." And my dad's like, "If you suspend them out, you put them on the street! Like, what are you doing? You know, you can't do that! They've got to be in school!"

\section{Emma}

Emma taught for almost a decade before becoming an administrator. She sees the time she spent in the classroom as a key component to her success as an administrator:

I am biased when it comes to spending considerable time in the classroom before you become an effective leader. Just simply because I think the leaders that I have worked with that I feel like have been the most influential, the most empathetic have been the ones that have been in the classroom long enough to feel the pendulum swing from one place to the next and experience that as a teacher because that's...just a constant in education. I feel like the leaders that have been in the business with boots on the ground long enough to have experienced what that feels like to have to be accountable to a moving target have been the ones that I feel like can really grow teachers the best. 


\section{Faith}

Faith is the youngest of the participants, with a decade of total time spent in the field of education. When reflecting upon her views of teacher leadership, Faith points to the influence an early colleague had on her mindset:

He introduced me to this world of teacher leadership, and I was like, "What is all of this?!" The whole point of the program and the district [he showed me] was to be super innovative and creative and basically be curriculum designers instead of following [old rules]. And I fell in love with it and it totally became like, "Oh! This is what education is supposed to be!"

\section{Graham}

Graham has spent almost 30 years in education, and all of those have been in the district where he currently serves as principal. He was also born and raised in the community in which he serves, and sees the idea of his community growing their own set of leaders as a rewarding part of his profession:

I think it's very important to have people who want to give back to their community that they were brought up in. I'm at the point now where I'm hiring young people who I taught. I have people here who went to [our school], have gone on to college and graduated. And now, if I'm able to bring them back into the fold, then it means a lot to me to do that if I can.

\section{Heath}

Heath's journey in education began over twenty years ago. Like several of the study's other participants, Heath currently works and lives where he was raised, and 
places a great deal of importance on the standard he sets for himself both within in his school throughout his community:

I think there's a certain obligation when you're in a role like this. You're not going to see me at the local restaurant in town drinking a beer because someone in this community's going to see me. I just think we're held to a different standard.

\section{Ian}

Ian has over twenty years of educational experience. When discussing his teachers and the recognition they get for their hard work, Ian had the following insight: There are a lot of kudos that are shared, and parents love our [Advanced Placement] program and... a lot of the teachers that have been doing AP a long time and have been doing it really well. I think in our community [those teachers] are seen as fantastic teachers, and they are great. But then there are other teachers in our building that are doing fantastic work that never get the same kind of recognition. And so, we're trying to find a way to [recognize others], whether it's in faculty meetings or through the work they're doing because they're doing some amazing work with kids, they never really get the public recognition for it.

\section{Jacob}

Jacob is a veteran administrator and educator who has almost thirty years of experience under his belt. Early in our conversation, Jacob described why he fell in love with his job:

I just fell in love with [the field of education] from the beginning. I always, I get bored really easily, and so I always like a challenge. So that was something that did always challenge me, like every three or four years I wanted that something 
changed. I loved having something new. I never had the same prep two years in a row when I was teaching, and then when I moved to administration, it was a constant challenge and change. We were constantly evolving. It wasn't just come in and do that same thing every day, so I liked it. It's kept me engaged, and like saying since, and I've always been a proponent to the underdog. That's always been my thing of wanting to be sure that those that didn't have a voice had a voice, and those that didn't have opportunities had those opportunities.

\section{Karen}

Karen is a principal with over twenty years of experience, and lives in the community where she currently serves as principal. In reflecting upon what brought her to the field of education, Karen had the following insight:

I wasn't going to go into education because both of my parents are teachers, my dad was a high school teacher, my mom was an elementary teacher... yet that's what I was called to do.

\section{Leah}

Leah currently leads the school that she attended in her youth. When talking about how she came into a position of leadership, Leah reflected upon the intrinsic motivation she has to lead:

I'm not like my parents. It's funny because their personality is not like mine. It's not like I came from a home of educators, and it's been driven in them. No. My dad didn't graduate high school. My mom's always been some type of clerk or something like that. I think sometimes you're just wired that way. There's some of you who are given gifts of different things and some days mine's a gift and 
some days people probably think it's the gift of hell... it's easy to get lost in this job and all of this.

\section{Defining Teacher Leadership}

In my discussions with the study's participants, they were asked the simple question: "How do you define teacher leadership?" The responses they delivered; however, were far from simple. Instead of providing a straightforward definition, most participants discussed two or three thematic ideas or talking points and expanded upon those ideas throughout our line of questioning by citing specific examples from their previous experiences. The two phrases that continued to emerge from the participants' conversations were "trust" and "empowerment." Virtually every principal in the study emphasized an almost a symbiotic relationship between teacher leadership and trust and empowerment when discussing their definition. Karen, for example, referenced the connection between teacher empowerment and student achievement:

I see it as empowerment to make things more efficient and more effective. And I can do that from the front of my classroom, I can do it in my classroom, I can do it in my department, or I can do it school wide. And then kind of, "How do you feed other people?" and, "How do you feed your peers and your students to kind of take those things on also?"

Ian echoed Karen's take on defining teacher leadership through a lens of empowerment, but also alluded to a second common theme that emerged in our definition discussions the concept of supporting teachers to be leaders. In Karen's case, she discussed supporting teachers by giving them specific resources to do their job effectively: 
To be leaders in multiple capacities, and to empower them to be leaders in the classroom, to honor their professionalism, their expertise. Provide them the resources that they need.

Empowerment and trust were used interchangeably in many of the participant's discussion of how they defined teacher leadership. Faith, for example, succinctly emphasized the importance of trust when defining teacher leadership:

Trust and a growth mindset. Also, being accepting of change or being willing to go through that process.

Graham made a connection between teacher leadership to teacher voice, which directly aligns to other participant's statements about trust, empowerment, and support. In the same breath, Graham also made a note that several of his counterparts in this study made: teacher leadership is about the impact a teacher makes, be it in their classroom or their school community:

Teacher leadership comes from teacher voice. When teachers feel like that they are invested in the welfare of the school, then they will expand their leadership skills to do that.

Anna emphasized defining teacher leadership through building trust, but also discussed the idea that became a central theme of the study's definition of teacher leadership: teacher leadership is an effort that should be personalized to the individual strengths of an educator:

I think everybody has the capability to be a leader. You just have to figure out through whether that's a strength finder or through relationships and trust helping people find what area they're really strong in and can lead. And so I think 
you have to have that growth mindset of... I was just always very fond of, no, you're going to lead. We all have the ability to lead, and we all have the ability to lead in a positive manner or in a negative manner... you've got to build relationships. Build a high level of trust in your building and offer opportunities to lead on a daily basis at big scale, and on a small scale.

Numerous other participants echoed Anna's view of teacher leadership being defined by building upon the individual strengths of teachers. Jacob, for example, connected teacher leadership to individual teacher successes and passions:

One of the main things I would want to do is to put people in a position where they can be successful, and places where their passions, where they could run with those strengths and passions. I believe people have much more room for growth in areas they're passionate about, than in areas where they're trying to patch up the weakness. I try to put people in areas of strength where they can feel good about themselves, where they can share a strength with somebody else.

Emma also discussed teacher leadership being defined through a lens of personalization, and as a result, becomes something that is owned by teachers themselves:

I think teacher leadership is any person in education who sees their position as double duty, not only to grow the flourishing of students, but also to help colleagues flourish in the profession. I look at teacher leadership as being something that's very personalized and can have a thousand different paths. I don't believe that teacher leadership happens directly up through the principal's office. I think for some that happens that way, but I don't think that that is the only way that you can be a strong teacher leader. 
Barrett echoed the sentiment of teacher leadership as an extension of personalizing potential to individual strengths:

Finding the best you. Finding what's best for each individual and directing them where their niche is - and sometimes they don't see their niche-I think that in order to direct teachers into leadership positions and have them experience that growth. The person above you has to trust you and be willing enough for you to know them to say, "You know what? We really need to take [a teacher] and we really need to see what we can do to create whatever it might be." Pick an area and move her or him in that direction. And they had to be willing to help you along to do it, because you know you can't do it alone. You have to have them, or you can't support it.

Heath also discussed individual teachers' leadership styles and the impact that has on instruction:

I think there are different leadership styles... I want to empower people. And this is stuff you hear where you put your strongest people in the roles in which they can serve the school the best. I am in no way, shape, or form the instructional master of the building.

Similarly, Leah discussed defining teacher leadership around the idea of building capacity:

But for me, leadership, absolutely 100\% is about building capacity of others. Sustainable capacity in their strengths that match who they are as people, and alongside that, giving them the opportunities to be able to display that within their work environment. 
When asking for her definition of teacher leadership, Danielle gave an anecdote about empowering and supporting teacher movement and leadership potential, and the happiness it brings to teachers:

I'm thinking about the teachers that moved into different [leadership] roles. One thing is that, through that happiness, they have a curiosity to think beyond the surface. And with thinking beyond the surface, not only do they think beyond it, but then they think through that problem. And so, I believe that my job is to facilitate, and helping them think through that problem no different than our teachers do with our students. And help them to work through that so that they can have the desired outcome.

In a similar sentiment to Danielle, Charlotte talked about the freedom and camaraderie that comes from teacher leadership:

When I think of teacher leadership, I think that they are those runners that have the ability to just lead their staff in a way that nothing is threatening. It's not, "I'm better than you." It's, "We're all in this together. You need something. I have something we can learn from each other."

The twelve principals in this study overwhelmingly defined teacher leadership through a lens of trust, support, and empowerment. Our conversations pointed toward teacher leadership as a mechanism for building upon the strengths that teachers already possess, and an effort that should be personalized to each teacher's individual skill set, experience, and circumstance. No two teachers are alike; therefore, a definition of teacher leadership should address individual needs. Ultimately, defining teacher leadership always centered back to the impact teachers have on their colleagues and their communities. Through my 
conversations with the study's participants, the following definition of teacher leadership evolved:

\section{Teacher leadership is the process of trusting, supporting, and empowering teachers to positively impact their schools and communities in a way that builds upon individual teachers' strengths and interests.}

To ensure this definition was an accurate representation of both the interviews that were conducted, as well as the beliefs of the principals themselves, the study's definition of teacher leadership was shared with each participant via email. In our correspondence, the participants were invited to correct or add onto any aspect of the definition, as well as to provide any feedback on it. The participants who responded confirmed that it was an accurate representation of our conversation and made no suggestions for revision.

\section{Shared Administrative Teacher Leadership Beliefs}

\section{Relationships Matter}

Principals who cultivate teacher leadership put an enormous, intentional emphasis on building relationships with the teachers in their buildings, as well as with fostering relationships among their staff. In order to make any large-scale impact on classroom instruction, building-level initiatives, or school culture and climate, principals who create teacher leadership opportunities believe that positive relationships are the most

meaningful endeavor they can take on. As Ian noted:

You can create all the systems you want, but if you don't build relationships with those teachers and get to the point where you're small talking in the hallways, you're not going to get anything accomplished. 
Establishing positive relationships is central to a building teacher leadership. Principals who cultivate teacher leadership believe that positive relationships with all school stakeholders - from teachers, to students and parents - help reinforce these efforts. When principals set and model the types of relationships they expect their staff and students to adhere to, it creates a shared sense of purpose. Jacob, for example, noted that relationships are at the forefront of the way he leads his school:

Foundationally, I believe in the power of relationships, if that's between administrator or teachers, teachers to students, administrators or students. You know that nobody cares what you know until they know that you care. That's where we start everything here at [our school], with relationships.

Another aspect of positive relationship building is that it creates a sense of empathy and understanding between teachers and administrators. Many principals discussed the impact that sharing meaningful experiences with staff members had on the relationships they were able to foster among their staff. These can range from taking part in a professional development opportunity together, to being empathetic and sharing a story that connects to what a struggling staff member is going through. Leah embodied this idea when she stated the following:

Part of building leadership within somebody is you have to have a relationship. You can't just tap it on to a teacher. You've got to have these experiences with them where you get to grow together. You get to experience what it's like to be an educator and cross paths of hard times and good times.

Believing in positive relationships leads to a strong sense of comfort between administrators and teachers, which greatly aids in promoting teacher leadership efforts. 
This comfort allows principals to show teachers that they care about them more than just as employees, but as people, as Barrett discussed:

And you have to be willing to let them tell you exactly either what's right, what's wrong, or what they want to do, and they have to feel... You have to build up a relationship, you have to have a relationship with them that they are comfortable enough to tell you anything at any time and approach you about anything at any time. And then you've invested in them. You know what did Maya Angelou say? She said, "People will forget what you say, they will forget what you do, but they'll never forget how you made them feel." And that's what you have to do with teachers.

Heath echoed the connection between building relationships with staff and the comfort that follows, and outlined how teachers' relationships with administrators allows them to get additional support during difficult situations:

Every year, and this has been since year one, we start the year off not just building relationships within the school, but from us with teachers. I don't think there's a teacher in this building who is afraid to come to myself, my AP, our counselor or instructional coach that makes up our leadership team. There's not a teacher in the building who wouldn't feel comfortable coming to us with any issue. If a teacher has an issue with a parent, they know after a couple of times, if they're coming back, you forward it to me and it's mine. And if we meet, you're never meeting with a parent alone. It's going to be the team, because we're a team and everybody can speak and one of us going to be there with you. We're not going to throw you to the wolves. 
Building relationships not only leads to teachers being comfortable with school administrators, but it also serves as a way for principals to get more authentic feedback. The ability to receive honest and actionable feedback is critical to being a successful principal, and many of the participants noted the connection between establishing positive relationships and getting authentic feedback from staff members. Anna expanded upon how those three ideas are connected:

When you are building relationships, you trust the people that you worked for. You have to be willing to ask them for feedback and take that feedback to help lead you to a decision. I feel like all stakeholders need to be involved... from your students and parents, to your teachers. But it's about shared leadership, and I would seek out the input from others, and especially if it was a hot topic, because of our relationships, and knowing people's strengths.

Principals who have been found to promote teacher leadership see building positive relationships with staff as an absolutely integral element of their work. Fostering a positive relationship with teachers, when done authentically and purposefully, leads to a trusting relationship with staff, and ultimately models the type of relationship administrators expect teachers to have with their students.

\section{Trust Teachers}

Establishing relationships with teachers helps build trust between staff members and administrators. In the same vein, in schools where teacher leadership is promoted and encouraged, principals believe in trusting their teachers to do their jobs and lead building efforts together. Karen discussed the reciprocal trusting relationships schools should have: 
School has to be a trusting environment. [Teachers] have to trust that I'm not going to zing them if something doesn't work, and that I'm not going to hang them out to dry. Also, I have to trust that they're making decisions for the right reasons. It's ongoing support back and forth.

Multiple participants noted that teachers should be trusted to be the instructional experts in their classrooms. This can range from giving teachers the freedom to plan and design instruction, to trusting them to make decisions about when and how to give assessments. The study's participants noted that they give their teachers general expectations and guidance to follow, and allow them the flexibility to adapt it to their strengths, as Ian alluded to:

You trust [teachers] as professionals. You guide them from a standpoint of ensuring that the instruction taking place in their classroom meets the standards. [Administrators] are setting those parameters and coaching teachers, and we're trusting that they're doing it the right way.

Heath echoed the sentiment about trusting teachers instructionally, and emphasized the need to support them throughout the planning and teaching process:

We're trusting teachers to do their jobs. Educators, you're the professional, you know what you're doing. I'm not a [content] teacher. I taught years ago, but you're the expert. Go do it. And how can I help you do it?

Teachers can establish trust with administrators by proving their work ethic, preparedness, and their care and compassion for students. Once teachers have proven themselves, as Charlotte noted, they should be afforded more autonomy: 
It goes back to being treated like a professional and giving teachers some autonomy to do what they do. As long as a teacher proves to me that they are a runner and that you're willing to go the extra mile, then they have my support. Establishing trust with teachers gives administrators an additional method of inspiring teachers to push their instructional craft further. Barret described this concept as allowing teachers to take a chance on an idea, and for principals to not be afraid to say "yes" to an idea or an initiative a teacher wants to take on:

The person above you has to trust you and be willing enough for you to know them to say, "You know what? We really need to take [a teacher] and we really need to see what we can do to create whatever it might be." Pick an area and move her or him in that direction. And they had to be willing to help you along to do it, because you know you can't do anything without their support. You have to be willing sometimes to roll the dice on somebody and say, "You know what? You can do this." Sometimes you need to be point blank and say to [a teacher], "You can do it. You have the ability to do that."

Principals who believe in trusting teachers understand that it is a process that takes time. Danielle described taking over a building where trust wasn't present before she assumed the principalship, and how critical building trust with her staff was to the school's success:

It took two years for our teachers to laugh or applaud anything, and that's because we had to build trust. The more I made them a part of decision making, the more they began to trust... You're only as strong as your right and your left hand. And so many times we forget that our right and left hands really are our 
teachers. And if we continue to build them, and trust them, and help them to be successful and supported, that it makes our job easier and our school better.

Emma also assumed the principalship over a school where trust needed to be developed among the staff. Emma quickly learned that trust has to come before initiatives and building-level beliefs can be ironed out:

The modus operandi for a school leader is to operate always with the sense of urgency, but that's not always the best thing for the situation. I think that's a critical part of teacher leadership because you're operating with people's values and beliefs when you're growing teacher leaders. If you move too quickly with values and beliefs, you can really quickly do some damage to a trusting relationship.

Trusting teachers to teach and lead must be actionable, according to the study's participants. Building leaders cannot simply say, "I trust you," while running schools in a way that is counter to that message. Principals who believe in teacher leadership show their staff they trust them by giving them freedom to make decisions, encouraging their ideas, and allowing them to determine what instruction should look like in their classrooms.

\section{Honor Time}

Principals who cultivate teacher leadership believe in being mindful of the time expectations they place on their staff and see a connection between respecting teacher time and empowering them to lead. Many of the principals in this study see time both a barrier and an asset. They note that the teachers in their buildings constantly state that they don't have enough time to do their work, and that by finding ways to give them 
time — either after school or doing the school day — teachers feel more honored and respected. Jacob spoke of how he constantly strives to be respectful of teachers' time, and about how removing time barriers allows teachers to focus on student achievement: The first thing I want to be very respectful of their time. I don't take their planning periods, we don't do before school, or after school. If we do [hold a meeting], they know that it's something big, and that we're going to come together. If I can share it in an email, we don't need to sit in a meeting to do it. If the mandated time is during your planning, things like that that just absorb teacher time. I want them to be focused on kids as much as I can, every moment that they're here, they're focused on their craft and their kids. I've tried to strip away any useless paperwork, any things of just turning things in to be turning things in. If I'm not going to have the time to monitor it, I'm not going to have them do it.

Honoring teacher time isn't as easy as simply not holding meetings. Principals who promote teacher leadership believe in the power of proactive scheduling and intentional communication in order to remove time barriers from teachers. Heath described how both his planning, and his philosophy on respecting teachers' time, coincide:

I do a weekly message and all that. And if they get an email from me, it's usually just once a week, that's it. When we do team PLCs, they don't lose their planning period. We work it out where we value your time, you are the instructional leader. You are the driving force to the success of the school. I'm valuing your time. I'm not going to meet just to meet, I'm not going to send out emails just to send emails. If I meet with you, you're going to get your time back, and that's the collective environment. 
Heath then transitioned to make a connection between respecting teacher time and building relationships with students and staff:

Other people were like, "How can you not meet?" Our [other schools] are meeting constantly, they want more meetings. I'm like, "Why?" If I can walk around and talk to the team leader, why meet? It's just a quick walk down the hall. It's about making personal connections.

Whereas some principals believe in having as few meetings as possible to respect teacher time, others simply see value in knowing when to cancel a meeting or adjust a schedule. Faith, for example, described how being empathetic of what it was like to be in the classroom motivates her decisions with calling meetings and taking teacher time up:

There was a moment last year where I felt like I got sucked up in that admin world. I was like, "I promised myself many times never to do this," so I tried to continue to remember what it was like to be in the classroom. Because of that, sometimes I feel like a faculty meeting need to be canceled, because at this point, what's going to be worth it? They're all just going to kind of stare at me or are we really going to be productive in this PLC? Is it better off using their time to focus on the work? Sometimes I think schools put in structures just because somebody said to, but is it really what needs to happen at that point?

Faith then expanded upon how removing teacher time barriers can initially make teachers feel uneasy, especially those who are used to meeting on a regular basis:

Some of our teachers have been in the game 20 some odd years, and no one has respected their time, and nobody has really given that. So, they think, "I have this freedom. What am I supposed to do with it?" Some of those challenges are okay: 
What does this look like? What does this freedom look like? What does this creativity look like? Some teachers, though, get frustrated with that. Helping them through those frustrations and reminding them that it is okay to make some mistakes is how we move forward.

Honoring teacher time comes down to recognizing the demands of teachers' workload and understanding that their emotional and mental wellbeing is a critical part of their success in the classroom. Furthermore, principals who promote teacher leadership note the connection between honoring teacher time and "shielding" them from extra work or initiatives that might be counterproductive. Charlotte noted the connection between these two ideas:

I tend to shield [my teachers] from things I think they can be shielded from and give them plenty of time to do what they need. We have to always keep our students in mind, but we also have to keep teachers' mental and emotional health in mind too. Giving teachers time and space to breathe is a big part of that.

Principals who cultivate teacher leadership understand the adage "time is a finite resource." Giving teachers time, be it by drastically scaling back on meetings scheduled, or by clearly communicating, and sticking to, a pre-determined schedule of events, shows teachers that they matter, and are trusted and respected. The idea that teacher time should be respected and protected is a foundational belief of principals who create teacher leadership.

\section{Culture is King}

Building strong relationships, trusting teachers to lead, and respecting teachers' time all lead into a key administrative belief: a healthy school culture is critical to a 
building's success. In schools where teacher leadership is present, administrators believe in creating a supportive, welcoming, and fun school environment. Culture is a concept that should be constantly cultivated and should be the focus of any principal who wants to improve teacher leadership efforts in their schools. When assuming a principalship, culture needs to be a top priority for principals who want to increase teacher leadership efforts, as Charlotte described when she reflected on taking over at her current school: I wanted [our school] to be known as a school that people want their kids to come to, that people want to be a part of. I wanted it to be a friendly and inviting place for kids to learn, for families to be a part of. When you walk in this building, I want you to feel like you're wanted. You are part of our school family. A big piece of getting there was, "Okay, how do I flip this culture?" You can't go in and change everything they want. "What can I do a little bit at a time to try to flip this culture?"

Culture is so critical to promoting teacher leadership that many principals see it as the most significant aspect of running a school. Jacob emphasized that culture and joy is the backbone of his high school, and that without a firm school culture, instructional strategies are insignificant:

I'm a firm believer in culture trumps strategy every day. Yes, you've got to have a strategy, but culture wins every single time... We're all going to be positive every day. We're all going to bring energy every single day. We're going to get the kids excited about being there. This is going to be some place where you just don't have to be for seven hours. 
Several principals described a similar strategy for creating and sustaining school culture: the implementation of a yearly "school theme." This school theme is usually a few words or phrases, like "Driven to Excel," and allows staff members to have fun and frame their work around a unifying concept. Several principals, like Heath, described having staff dress up days that coordinate with the school's yearly theme:

We're having fun. Every year [our school has] a theme, like cultivate strong relationships, grow professionally, produce. Whatever the theme is, we are all in. We make a video; we dress in costumes. And they're seeing us act like fools basically. That's why I say we have no shame, it's bad but we make it fun. We make it about building the team with just with us and them within the units. We have new teachers and things like that, mentorships, just making them feel like, "Hey, this is something different here. Something special to hold onto, unlike anywhere else. Appreciate working here and roll with it."

Other principals described nurturing school culture by creating a series of school traditions. The traditions can range from school-wide events to awards that are given to staff and students. Graham described a yearly tradition that originated from an idea one of his teacher's had witnessed at another school:

[Our staff does] something now where we have a bowling pin. It has our middle school logo on it, and each month a teacher gets to give it to another teacher. You're doing something great in class, or you're doing something great beyond the classroom for school culture? [Teachers are] making the decision to highlight somebody... I don't know if it's necessarily a system, it's just what we do. It's just our culture. 
In conclusion, creating and sustaining a health school culture and climate is another foundational belief of principals who cultivate teacher leadership. Many of the study's participants noted that a strong school culture impacts both teachers and students alike, and that creating a school that is fun, welcoming, and exciting is something that all stakeholders can get behind. Similarly, the principals discussed how a school's culture builds over time, and that many of the previous themes—-such as respecting time, building trust, and forging strong relationships—all feed into a school's culture efforts.

\section{Mentorship Shapes Experience}

Principals who consciously cultivate teacher leadership believe in the power of educational mentorship. Every principal who participated in this study spoke vividly and glowingly of a mentor who shaped their view of teacher leadership and education, and who groomed them to become leaders. The advice, modeling, and relationships they built with these mentors has stuck with the participants throughout their careers, and regularly serves as a lens for them to look through when making decisions in their own buildings. Danielle described the high expectations her mentor had of her staff members, which had an impact on the administrator she wanted to become:

[My mentor] expected excellence, but also had your back. And I would say expected excellence because she always wanted us as teachers to have the same respect as anyone else out in the business world. But when I say expected excellence, you had to come with your A game. You had to come and look the part, be the part, act the part. And what I mean by that is not only how you present professionally, but also your lesson plans had to be ready. You had to be on time to a meeting. But if there was ever a problem with parents, she backed 
you up. She always gave you support. [My mentor] was most definitely a person that I always tried to be each and every day... she helped to encourage me, which helped me to overcome fears, which helped me to then take risk. She just, gosh, she's phenomenal. Phenomenal.

Charlotte shared Danielle's experience with her mentor instilling a sense of high expectations with compassion:

[My mentor] was instrumental in shaping me as a leader, period. She was one of those that taught me that you love a person no matter what their circumstances are. "You don't love them dumb," was her term, not my term. And I never could figure out what she meant. But she's like, "We make excuses, and we alter our expectations because of their outside influences, and we can't do that." She said, "You nurture them, you love them to death, but you also have very high expectations for them," And to this day, that resonates with me.

One way that the participants' belief in mentorship helped to shape many of their experiences is by forcing them to operate outside of their comfort zone. From their mentor having a different disposition or personality than the principal, to their mentors asking them to take on initiatives or systems they weren't familiar with, the principals noted that these moments made them grow as leaders. Graham, for example, described that his mentor led in a style that was different than his natural inclination, allowing him to develop as a leader:

[My mentor] was very strong in her convictions. And in some ways, that's an area of growth for me because I want to listen to what every person says, and then say, "Let's all come together. Let's all Kum Ba Yah a little bit." And she would just 
come in and say, "No, we're just going to do it this way." And that's okay. Both styles are not wrong, it's just she was much stronger in that style of leadership. She felt comfortable enough to say, "You can tell me what you think, and it's okay, but when we walk out this door this is the way we're going to do it, alright?" I learned so much from that.

Beyond their mentors putting the principals in situations that were out of their comfort zone, many of the participants noted that their mentors were adept at having hard conversations with them. Similar to when the study's participants were given a unique experience by their mentors as a point of personal growth, these difficult conversations allowed the principals to reflect and grow in their leadership capabilities, as Graham noted:

As much as [my mentor] built my capacity to be a leader, he also very much held me accountable. He asked the tough questions. He has some hard conversations with me. I think he just prepared me in a way that sometimes was out my comfort zone, but I needed that to grow... Sometimes we have to have those tough conversations, and that's definitely something I'm still working on.

One of the most long-lasting impacts the principals' mentors had on them was recognizing potential in them that they didn't see in themselves. Emma explained how her mentor homed in on her potential by constantly pushing her to pursue new opportunities:

[My mentor] noticed leadership potential in me before I noticed it in myself. They were always offering things like, "Can I ask you to take this on?" "Can I ask you to be in this?" Then there was one conversation where [she] said, "Fall's coming 
up. You need to be in an EdS program for your principalship". I said, "Screw you. I don't want your job!" They just questioned me around it. "Why don't you want the job?" My fear was all about being afraid of burning out, which has made me a strengths-based leader.

Jacob was in the unique position of spending almost a decade with the same leadership team, which taught him the power of meaningful collaboration:

We had our whole administrative team stay together that whole nine years, which was very, very rewarding. [My mentor] was vibrant. [She] was amazing as far as empowering those under her, and really, I couldn't have stayed in a place where I was just dealing with discipline for nine years, or you know what I mean? It was very much we all had a very strong voice in what we were doing. We all brought a lot of different ideas at the table, had great discussions on innovative new ways to do things, and challenged each other. It was a situation I probably could have moved from earlier than that, but it was just very rewarding.

Many of the beliefs, values, and structures that are critical to creating teacher leadership are learned through the guidance of a strong principal mentor-mentee relationship. This is a critical belief of principals who cultivate teacher leadership, for in most instances the principals are so shaped by their experience with their mentor, that they look to replicate that sense of potential in the teachers in their buildings.

\section{The Challenges of Teacher Leadership}

\section{Missing Pieces}

One of the largest pitfalls that emerges when creating teacher leadership opportunities comes when a teacher wants to assume a leadership role, but still need to 
grow in their capacity as a leader. These areas of growth can range from organizational deficiencies, like missing deadlines and being late to meetings, to dispositional traits, like being hot tempered and combative. Emma mentioned the challenges that emerge when a teacher wants to step up as a leader, but initially falls short:

I think the toughest place is when I see really hard workers that want to be out there in the forefront as teacher leaders and are just missing a piece. For each one of them, it's a different piece. I can think about a teacher that has gone through [a principal preparation program] and for all intents and purposes should be ready to jump out there in front but is a terrible relationship builder. How do you coach that without crushing someone? Then I have another person who can lead in certain situations, but then in other situations their anxiety just goes through the roof. They, pardon my French, lose their shit all the time. I know you want to lead in this arena, but this is not good for you. Because of your stress, it's not good for kids. Because of the stress it creates, it's not good for your team. It's the snowball effect of there's just a missing piece.

When working with teachers who are aspiring leaders, but are falling short, it is important to continue to coach those individuals without crushing their goals and spirit. Several principals noted the coaching cycle as critical to helping aspiring leaders gain a missing piece, and as Emma noted, sometimes that can mean pointing someone's attention to an opportunity that exists outside of their current building placement: I think one of the challenges is that not everybody can serve in a leadership role... I've had some conversations with a couple of teachers about, you know, "Maybe we need to go to cognitive coaching training so that you can really be an active 
listener and listen to what people are saying." Or it's, "How can I help you if you really want to be a reading recovery teacher, and are not able to do that because you're in the classroom? It's not going to work for you to be an interventionist here. How could you be an interventionist so you can do that with [district staff]? And if not here, then where?"

Principals noted other instances where aspiring leaders in their building simply needed to expand their ability to have open lines of communication. This can range from teachers having the ability to have a constructive conversation about an issue without veering into negativity, to being openminded about feedback, as Karen illustrated:

[Teachers] have to be comfortable having an open conversation where it's okay to ask questions, where we go back and forth and say, "Well, I don't know about that, but what about something different?" Or it's okay to try [an initiative] and then come back and be like, "It didn't work," or "I need help," or "I need support," or "I need this kind of thing."

Sometimes, a missing piece is as simple as teachers not having the confidence to lead. Several principals, like Barrett, mentioned a gap in teacher confidence as a potential barrier, and alluded to working with teachers to build their self-efficacy without crushing their spirit:

The one thing that is really difficult to do is when you have [a teacher] who is a born leader and needs to go and pick a direction. Whatever curriculum, administration. Whatever it is... they are hesitant. They don't want to. They feel reluctant, they're not confident. So, I have found the biggest obstacle is building that confidence back into them. You have to create the things to build the 
confidence without them knowing you're creating them, and that can be easy sometimes, but sometimes it can be difficult. But I have done it and that that is the biggest obstacle.

Having the ability to recognize these pitfalls and being able to positively and proactively assist teachers in reaching their goals and potential, is part of being an effective principal who promotes teacher leadership. The study's participants all described these areas of growth as just that: areas for teachers to improve upon. None of the participants verbalized these "missing pieces" as something that aspiring teacher leaders could not overcome. By assisting teacher leaders with pursing their aspirations, and through helping them overcome their "missing pieces," principals can continue the cycle of mentorship that is critical to growth and potential.

\section{Equitable Opportunities}

All teachers need to be given opportunities to lead, which can quickly turn into a challenge. Principals mention the need for creating equitable opportunities as a challenge, especially when it comes to the perception of some teachers getting more leadership chances than others, as Charlotte mentioned:

You've got to be careful with creating the appearance of "haves" and "have nots" by showcasing certain teachers all the time. You never want to make any of your staff members feel like there's favoritism, or that only certain people get to do certain things. It's a challenge, because nine times out of ten, the runners are the ones that get their backs scratched because they are running hurt. [Teachers] can't come in here tardy and then expect to get everything [they] want without putting in the work! 
Allowing teachers to perceive that they have equitable opportunities is just as important as actually giving them opportunities to lead. Principals who promote teacher leadership need to be very cognizant of not giving the impression that they are handpicking a select group of teachers to take on everything, as this mindset can quickly become toxic, as Danielle described:

I have a staff member that very much sees herself in a position and not a job. And so now she has seen others in leadership positions and it's wondering, "Why not me?" And so, the greatest challenge I've sometimes had is that, and I've had to be careful of this, is that it's not [Danielle] handpicking teachers to take things on.

Giving younger, less experienced teachers opportunities to lead can also be perceived as inequitable to more experienced teachers. Ian recalled an experience where he had a group of young teachers who were highly motivated, and discussed how that was perceived from some of the veteran teachers in his school:

And there are some fairly young teachers who quickly have risen and have those kinds of natural skills to build consensus and facilitate conversations. It can actually be difficult for teachers that have been here a while or have been in education long enough to see someone else getting an opportunity.

In some situations, the inverse of Ian's problem can occur, where younger teachers or newer teachers to a building are reluctant to engage in teacher leadership efforts, as Graham discussed:

We had some staff turnover, and with turnover comes new people feeling like they should say something, or they don't feel like they have that ability yet. It's just uncomfortable for them. We hire people a lot of time with experience; they come 
in from someplace else. And yet they were leaders there, but they're kind of trying

to find their opportunity here. That's the hardest part.

Combating the appearance of favoritism, and giving teachers equitable opportunities to lead, can happen through intentionally selecting different teachers for opportunities in a building based upon their interests, strengths, or identified areas of growth. Principals must be intentional about consciously cultivating teacher leadership in order to prevent adversely impacting teacher performance and potential.

\section{Consciously Cultivating Teacher Leadership}

\section{Formal Committee Structures and Systems}

Principals who are proficient at creating teacher leadership within their buildings do so by utilizing formal committee structures and systems designed to maximize teacher potential. As Anna perfectly noted, "If you don't put a structure or a system in place to support where you're trying to go, then it's just a lot of fancy words." Several principals mentioned utilizing committee systems to address particular areas of need within their building, and some even go as far as letting their teachers dictate the topics of these groups. One commonly mentioned committee system revolved around supporting new teachers - be they new to the profession or new to a building. Danielle, for example, noticed that her first-year teachers had a sizeable knowledge gap when it came to the ins and outs of her building, so she created a committee structure to address the problem:

To facilitate new teacher leadership, we have a program called [Name of School] Learning Project for our brand-new teachers. If you're new to teaching or new to [the school], then you have to go through the program. They meet once a month, and we try to tailor it to their needs. So, if it's a teacher with experience, we don't 
have you go through the session on how you handle a report or how you handle a parent teacher conference. However, we do have them go through what our school report card is and what mastery looks like.

In Kentucky, a prominent, state-mandated committee structure is the School-Based Decision Making council, or SBDM. Administrators who consciously cultivate teacher leadership recognize the teacher leadership potential of SBDM. Since SBDM is an elected position that is voted on by staff members, it is a critical structure for principals to leverage in order to promote teacher leadership efforts. Barrett discussed how he encourages staff members to present new ideas at SBDM meetings:

I said [to my teacher], "You know what, why don't you all come to the next [SBDM] meeting and just lay out what you're thinking about. What we need and what we're seeing." And of course, along the way, we sat down and looked at math scores, we looked at trends, looked at the data, and the council came up with a game plan.

School-Based Decision Making Councils, since they are more formal in nature due to the fact that members are responsible for creating school policies and procedures and monitoring student achievement, are often times more formal than other structures. Due to its formality, many principals who promote teacher leadership incorporate additional, looser committee structures in their buildings in order to reach more teachers. Ian, for example, differentiated between his SBDM and a less formal, but equally important group in his school, a Guiding Coalition: 
Our Guiding Coalition, I think of that as the philosophical alignment of our school. We spend a lot of time talking about the test score data and social and emotional health.

The looseness that I inherently put into that group, it's given us time and opportunities to have a lot more of a conversation versus discussing a really hardcore set of policies and guidelines [in SBDM]. Although we have some conversations with [SBDM], but it's voting on policy and approving minutes. Guiding coalition is really the teacher voices in the building that represents every pocket of group in the building. Every person in the group can say, "Okay yeah, my voice was represented."

Anna's school utilized a structure that was virtually identical, both in philosophy and purpose, to Ian's Guiding Coalition. Her school pulled together team leaders from across grades and content levels in order ground their school around a common vision, mission, and purpose for their work together:

If you're going to rally the troops, you need a little bit of positional power and by finding out who has a whole lot of influence on their peers. And so, I formulated a team, I can't remember to this day what the team was called, but basically it was a leader from every grade level: teacher representatives, and then essential arts, and then the administrative team. We met to determine our big rocks, and then began to plan. Because when you're in the thick of it, you can talk about all the things that you didn't do. But it wasn't all we didn't do. It was what are we going to do? Here are our big rocks. How are we going to approach this? This group helped with determining curriculum needs. 
Committee structures help to emphasize teacher voice and allow staff to make meaningful decisions that impact their work. Principals who promote teacher leadership also see these committees as ways to get teachers to embrace an idea or message that would fall flat if it were seen as a direct mandate from an administrator. Involving teachers in these conversations only strengthen teacher practice and efficacy, as Karen described:

Every teacher has a big say; they all feed into each other and they all support each other. Let's say an English teacher says, "We really need you all's help. We want everybody to do Reading Plus 10 minutes every Thursday." Let's say the teachers were going to do that. Well, the way [administrators] used to do it was we would try to tell them [the initiative], and then everybody would be mad. But if it comes out of this committee, then it can filter through to the staff.

Beyond using committees to explore new initiatives with teachers, principals also utilize these structures as a way to engage teachers in meaningful conversation with one another around a common purpose. When these structures are utilized with teacher voice in mind, and teachers can see that their conversations are actionable and impact their work, teacher leadership flourishes. Jacob, for example, emphasized how a group of teachers came together to take on a new building-wide initiative, and the empathy that was shared as a result:

We all came together. This group, we all had voice, and we all were like, “Alright, this isn't working for me. What's working for you all? Who is handling this well?" It was things that we constantly got to recalibrate and get everybody back focused as on the prize. "Alright, let's go back out. Let's try this again in 
three weeks." I think that people saw their voice was heard, and I even told them, I said, "This was going to be really huge for me, and that look, I'm supposed to be the leader here, and I don't know any more than you guys do. This is brand new for all of us, and pretty soon you're going to be way ahead of me because I've never taught this way.

From SBDMs to Guiding Coalitions, principals who consciously cultivate teacher leadership do so by creating and overseeing formal structures that make their beliefs and values actionable. Creating a series of formal committee systems within a school is a surefire way to give teachers a voice in their school's organizational leadership.

\section{Professional Learning Communities}

One specific structure that administrators use to promote teacher leadership is the Professional Learning Community, or PLC. PLCs, due to their focus on instructional practices and student achievement data, are one of the main instructional structures that the participants in this study used to promote teacher leadership. When principals look for a tangible building-wide structure to implement that impacts all facets of instruction, especially when they first assume the helm of a school, as was the case with Danielle, PLCs are a go-to platform:

PLC was probably the biggest [initiative] that I did when I first became a principal. It still never gets old because it's five easy questions that you just have to ask yourself about kids. That when you talk about teacher leadership and really getting to the meat of it, we didn't understand what a PLC was. I think it was very easy to say we're always PLC-like. Focusing on PLCs gave me a little wiggle room with [our teachers]. 
The PLC structure brings teachers together around a common instructional purpose. Principals who cultivate teacher leadership lean on the quick wins that PLCs reveal for teachers, through celebrating elements like student growth, teacher creativity, team accountability, and collegial camaraderie. Leah, for example, illustrated the sense of passion and community PLCs provide:

We're in year three of PLC work, which is a huge part of the work that I did [at our school]. Teachers are passionate about it, and I believe in it. And for teachers that have been allowed to be on islands, it brings them back in to our [instructional] community.

PLCs can be utilized to help build trust among a school's teaching staff. As previously noted, trust in teachers is a pivotal belief of administrators who cultivate teacher leadership. Administrators can lean on the involvement that PLCs allow them to have with teachers in order to garner trust with their staff. This is also advantageous for larger schools, like Heath's where the PLC structure allows multiple administrators to be involved with building instructional trust and support:

We do team PLCs once a month, and we have a core content PLC. I do not go to our core content PLCs. Our instructional coach, the [administrative] instructional leader, teachers have developed a trust with her. Her office is right outside at the end of the hallway, so she's with [administrators], but not with us. They trust her. They come to her with needs and planning. We let her do that, and we let PLCs be a non-threatening environment where I'll come and pop in every once in a while, or [our Assistant Principal] will, but teachers do their instructional [planning] with the instructional coach and rock it out. 
Like any effective structure, PLCs can be manipulated to fit the individual needs of a school. Many principals discussed the ideas of PLCs evolving over time and explained that they changed elements like the student data that is discussed in the meetings, the level of administrative involvement, and the frequency and duration of the meetings themselves. Faith noted an experience she had with "reversing" PLCs based on the needs of her school:

I've tried to reverse the PLCs... I felt like for the first part of the year we were meeting at PLCs and talking about the work and that's about all we were doing. So I tried to reverse it where teachers go do what we're talking about in their classrooms, and I'll come in and provide feedback. That way we can meet for PLCs when we have those big [formative assessment] data days.

Another adaptation to the PLC routine is to assign specific leadership roles within the meeting structure, like a facilitator, a timekeeper, and a recorder. Graham discussed how he assigns specific roles within PLCs, and then uses these roles to create additional leadership opportunities for teachers in the form of a structure he calls a "facilitator meeting":

Our grade level PLC's meet every Wednesday. The teacher who's the facilitator is in charge of having an agenda. They're in charge of selecting who's going to bring data to the meeting. It's their responsibility to make sure that the norms of the PLC are followed. It's their responsibility to make sure that we have participation. After our PLC, I have a facilitator meeting once a month where [teacher leaders] get to come to me and tell me what they need. 
If teachers are expected to lead from the classroom, it makes perfect sense that principals who consciously cultivate teacher leadership do so by putting a strategic focus on PLCs and building-level instructional efforts. Trusting teachers to be the experts in their craft and giving teachers a structure that allows them to examine student achievement, as well as their own effectiveness and growth, strengthens them as teacher leaders.

\section{Teacher-Facilitated Professional Development}

When looking for ways to grow teacher leaders, administrators who consciously cultivate teacher leadership place emphasis on teachers leading professional development — or PD — as a means of growth. Principals can use this structure to identify current and future teacher leaders and can give teachers an authentic way to sharpen their leadership experience. Anna, for example, described how her school's work with PLCs led to identifying teachers who were ready to expand their leadership through leading their colleagues' learning:

In the beginning, you kind of start off small looking for the leaders that kind of automatically rise to the surface... We started off with just professional learning communities, and bringing data and people having conversations where [teachers] could trust the group around them, and then you would realize that you could look at somebody and say, "Goodness, you really understand how to plan for small group instruction! I need you to get with the instructional coach, and plan a PD." Then you look for opportunities for people to exemplify that leadership skill.

Teacher-facilitated professional development often derives from a teacher or group of teachers who are passionate about a particular topic and want to learn more about it. 
Principals can use teacher interest in a subject to drive excitement about an idea or initiative across their building, and can then use a "train the trainer" model to have teacher leaders share the learning they encounter at a PD. This also becomes a costeffective means of getting multiple teachers' exposure to a new idea without having to spend money on an entire staff attending professional learning events. Charlotte described how her staff's hunger to learn more about an initiative resulted in teachers going to professional development, and then sharing their work with the rest of their staff:

I said to myself, "Okay, these [teachers] are really hungry and they really want to be out there." And so, I started to foster it. "You need PD, fine. We're going to get it. Know that this is the expectation. I expect you come back to come back and lead your staff in something." We started opening our doors to one another. It used to be, "Everybody go in there, close your door. You don't know who's against who. It's like, "No. I'm going to cover you so you can go or I'm going to get. So, you can go and watch such and such... You come back and help lead the team... During the summers we have PD, and we make sure that it's not just the instructional coach and me all day long. We bring in staff members that are well versed in content area and they can provide some PD.

Trust is a pivotal reoccurring theme in every facet of a principal's cultivation of teacher leadership efforts. Several participants noted an authenticity issue when presenters from outside of a building or a district present new learning to a group of teachers. Principals using a teacher-facilitated professional development structure allows for learning to be 
tackled in-house, allowing for trust to be authentically established before the training takes place, as Faith noted:

In other districts I hear about you usually have someone come in from outside and provide something, but ours was in house. Whatever questions we have, the answers are in this school. Building the trust with one another and knowing that if I have a concern, or a question, or a problem of practice, then somebody in this building is probably sharing that as well and then we can work through that.

Teacher-facilitated PD is a structure that allows principals to make their beliefs about teacher leadership actionable. Many of the beliefs that the participants noted about teacher leadership—like trusting teachers, establishing relationships, and cultivating school culture — can be fully realized through a principal emphasizing teacher-facilitated PD efforts in their schools. Graham described teacher-facilitated PD as one of the strongest teacher leadership moves he can make as an administrator:

The biggest opportunity we have is when teachers are able to get up in front of the staff [on district Professional Development] day. When teachers are reluctant, I tell them, "You're going to be great for that." We pushed all teachers, new and old, and said, it's not based on your years, it's based on your abilities.

Principals who are intentional about growing teacher leadership capacity in their building rely heavily on teacher-facilitated professional development. Giving teachers the opportunity to lead professional development efforts to colleagues allows teachers to grow as leaders, gives them meaningful opportunities to engage professionally with their colleagues, and encourages teachers to pursue additional leadership roles both within and outside of their building. 


\section{Teacher Feedback}

Principals who foster teacher leadership create structures for getting feedback from their teachers. The study's participants described both formal and informal structures that they implemented in their schools in order to receive authentic information from their teaching staff. The feedback they solicited covered a range of topics- teacher performance, administrative support, instructional effectiveness, and school culture and climate - and always was viewed as something that principals needed to hear, even if it ran contrary to their views and beliefs. Heath, for example, utilized a series of incredibly structured, formal teacher feedback surveys geared towards giving teachers a voice in their building:

In December, I give a survey, and it's anonymous. A good leader's always looking for ways to grow. How can [Heath] grow as a leader? Tell me about the leadership of [Heath]. Tell me about the counseling office, tell me about front office staff, custodial staff. Basically [teachers] have a chance to voice their opinion without me knowing who they are, and just be real.... I survey them again at the end of the year, and it's not anonymous. It's questions like, "Are you teaching what you want to be teaching?"

Are you with the teammates you want to be teaching with?" And I don't share the information with anyone else. Be real with me. If you don't like Ms. So and So, and you don't work well together, I need to know that. Because bad partnerships on the team, that trickles down to the kids and that's not good for anybody. You're unhappy with who you work with, you're unhappy teaching what you're teaching, we need to switch it if we can. We may have 13 different schedule variations by 
the end of it. But tell me, are you doing what you want to do? Is there something that you want to do that we're not letting you do? Do you have a desire to start a club or reach kids in a different way? Whatever you want to do, is there something that you're missing that we're missing in your leadership abilities? Internal surveys like Heath's can give principals honest and unbiased feedback; however, surveys aren't the only formal school-wide measure principals can take to get important stakeholder information. Danielle also created a formal feedback system in her school, but instead of giving teachers a survey, she simply guided her staff through an activity using a notecard. The goal of this formal feedback structure was to get teacher buy-in and enact meaningful change within her building.

When I first arrived at [this school], I gave everybody a note card. I said, "I want you to write three things that you want to keep, and one thing you would like to change." Before I was hired, the district brought in a retired principal to fill in, and the superintendent made some decisions to move a couple of staff members to different schools, which was not popular with the staff... One thing that [teachers] said is that they really wanted ownership on decisions. That's something they hadn't had before. So I said, “Okay." And so I put all of that information on a PowerPoint. I said, "These are the things that we want to keep, and these are the things that we want to change. Let's prioritize those." And that was the very first one they wanted to change; teachers wanted to be a part of decisions.

Teacher feedback doesn't have to be one way. In fact, some principals rely on committee structures to allow teachers to give and receive feedback to each other, and the school, on 
a regular basis. Karen developed a feedback structure she calls "Dialogue Groups," where teachers can hash out ideas and problem solve with administrators:

In the groups, I'll say, "Try [this strategy] for a little while, and then come back and tell me what didn't work and let's fix it, or let's adjust it, or let's start here." And different teachers act different ways. Some people I can say, "Hey, what do you think about this? Would you be interested in it?" They can take it to a whole another level. And then there are some people who are like, "Well, try this and then come back and tell me what needs to be done differently."

Instead of creating a new school structure to elicit feedback from stakeholders, some principals simply embed question and reflection protocols into pre-existing structures, like PLCs. This system allows principals to receive in-the-moment feedback without having to call another meeting for teachers to attend. Leah described how she began implementing this type of feedback structure:

I started by asking questions like, "Here's where we're at. Now what? Is it what you need?" I'd ask them, "What specifically do you find useful in our PLC lead meetings?" I did this with each of our groups. And then I asked, "What changes would you suggest we consider for next year? Give me an honest assessment of your leadership role and responsibility. Do you find being a PLC lead is too much? Or is it totally enriching in this specific end?" Just wonderful, really, really good, insightful responses came from this.

Not all methods of feedback need to come from formal structures. Many principals described the power that comes from simply identifying teachers who hold views that are contrary to their own, and approach them informally for feedback. Principals like Ian 
discussed seeking out these teachers informally, like in between class changes or by popping into their room during their planning period, in order to get honest answers to questions many other teachers might be reluctant to give:

I would say there are probably three or four teachers in the building, some of them aren't even lead teachers or aren't on guiding coalition. If there's a big problem to solve, I want to go to them, because they're the ones that are going to come up with the outside the box thinking. "Have you thought about this?" Poke holes in that. Trying to use them quite a bit, but then not use them so much that others think "Oh, we know who he's going to talk to about that" ... It's not a favoritism thing, it's just that I need their voice. I need to hear what they think because I value it because they're not yes people. They're not going to tell me what I want to hear. They're going to tell me what we need to hear.

Principals who cultivate teacher leadership believe in getting feedback from their stakeholders. Sometimes this feedback is formal in nature, via a perception survey or collection tool, and other times it can be as informal as striking up a conversation with a teacher about an upcoming initiative. Either way, the feedback a principal receives is only as good as what he or she does with the information. Principals who promote teacher leadership don't merely listen to teachers, they take their feedback and make it actionable.

\section{Chapter Summary}

Through collaborating with twelve insightful, transparent, and candid school leaders, a more complete picture of administrative efforts to promote teacher leadership unfolded. These principals, through contributing to a shared definition of teacher 
leadership, expanding upon their beliefs about teacher leadership, and sharing the structures they have used to support it throughout their buildings, have offered a rare glimpse into the nuts and bolts of successfully run K-12 schools. These twelve individuals believe, as Anna perfectly noted, that "everyone is a leader; everyone has a role to serve."

The final chapter will draw conclusions from the study's findings. Furthermore, I will examine the intersection between the themes in this chapter and the professional implications and the future research that can emerge from this study, and will reflect upon my experiences as a researcher. 


\section{CHAPTER V \\ DISCUSSION AND CONCLUSIONS}

\section{Introduction}

When Hattie (2015) recognized collective teacher efficacy_-"the collective belief of the staff of the school/faculty in their ability to positively affect students" - as the most impactful means of student achievement $(p=1.62, N=195)$, a new light was shone on promoting teacher leadership efforts in schools. While numerous studies have attempted to both define teacher leadership (Childs-Bowen, Moller, \& Scrivner, 2000; Crowther et al., 2002; Danielson, 2006; Darling-Hammond, Bullmaster, \& Cobb, 1995; Harrison \& Killion, 2007; Helterbran, 2008; Helterbran, 2010; Katzenmeyer \& Moller, 2001; Krisko, 2001; Lambert, 2003; Murphy, 2008; Reeves, 2008; Sergiovanni \& Starratt, 1998; YorkBarr \& Duke, 2004) and to outline a series of structures used to promote teacher leadership (Danielson, 2006, 2004; Klecker, Austin, \& Burns, 2000; Scribner, Sawyer, Watson, \& Myers, 2007; Sinden, Hoy, \& Sweetland, 2004; Vanblaere \& Devos, 2016), no study has attempted to reach out to a group of principals who has been objectively found to promote it. 
This study aimed to fill in the research gap by conducting a phenomenological study centered on interviewing twelve principals - four elementary, four middle school, and four high school—whose Kentucky TELL survey results indicated their strengths with promoting teacher leadership. This chapter will summarize the findings of the study, outline a series of professional implications, will provide my reflection as the researcher, and will highlight a number of potential areas for future research.

\section{Summary of Findings}

\section{Defining Teacher Leadership}

After asking the study's twelve participants about how they defined teacher leadership, the following definition was created:

\section{Teacher leadership is the process of trusting, supporting, and empowering teachers to positively impact their schools and communities in a way that builds upon individual teachers' strengths and interests.}

The principals interviewed highlighted many of the facets of previously existing teacher leadership definitions, especially when it comes to strengthening teacher practice and impacting student achievement (Childs-Bowen, Moller, \& Scrivner, 2000; Danielson, 2006; Darling-Hammond, Bullmaster, \& Cobb, 1995; Harrison \& Killion, 2007; Helterbran, 2010; Katzenmeyer \& Moller, 2001; Krisko, 2001; Lambert, 2003; Reeves, 2008; Sergiovanni \& Starratt, 1998; York-Barr \& Duke, 2004). This definition; however, reflects a new facet of teacher leadership definitions due to the fact that the study's participants overwhelmingly connected defining teacher leadership as a measure that should be personalized to fit individual teachers' strengths and areas of interest. 


\section{Shared Administrative Beliefs}

Principals who cultivate teacher leadership utilize strong interpersonal relationships to connect with their staff, and in doing so, motivate them to maximize their potential. The study's participants noted that building strong relationships with staff help with a range of issues, from making it easier to get authentic feedback from their teachers to modeling for staff members the types of relationships they expect from all of their school stakeholders. This reinforces the need for principals to believe in the power of collegiality (Sinden, Hoy, \& Sweetland, 2004) and supportiveness (Danielson, 2006; York-Barr \& Duke, 2004), and to build strong relationships with staff members from the first minute they assume the principalship.

Beyond building relationships with teachers, principals who support teacher leadership believe in trusting teachers to make decisions for themselves, their team of teachers, and their students (Sebastian, Allensworth, \& Huang, 2016; Vanblaere \& Devos, 2016; York-Barr \& Duke, 2004). The study’s participants overwhelmingly noted the importance of putting teachers in positions where they could flourish, and then trusting them to tackle the instructional demands of their jobs. Several participants noted that trust was earned over time, not given immediately, and that trust worked two ways: principals trusting teachers, and teachers trusting principals.

Time should be honored and gifted to teachers on a regular basis, according to principals who promote teacher leadership. By honoring and respecting the time teachers put in throughout the day, teachers feel more supported and encouraged professionally (Danielson, 2006). Principals who believe in respecting their staff's time make small steps like cancelling meetings when they feel their staff is overwhelmed, and also believe 
in making large moves like intentionally not meeting on weekly basis with their entire staff in order to give them meaningful time in the building outside of their work time with students. The principals in the study who are intentional about not holding meetings are strategic about their building-wide communication efforts and put other structures in place — like regular emails and planned class visits—in order to compensate.

Principals who promote teacher leadership believe in creating and cultivating a welcoming and positive school culture (Brezicha, Bergmark, \& Mitra, 2015; Carpenter, 2015; Deal \& Peterson, 2009; Drago-Severson, 2009). Some of the strategies the participants used to build school culture ranged from creating a yearly theme to tie fun school events and initiatives in to, from staff members giving out awards to one another to recognize hard work. Many of the other themes of this study, like trust and building relationships, also contribute to a culture and climate that is contusive for teacher leadership.

Lastly, the study's participants all noted meaningful mentorship they received as pivotal to shaping their beliefs about teacher leadership. The principals interviewed had mentors who put them in positions where they received constructive criticism and were allowed to grow and learn from their successes and failures. Many of the participants have maintained relationships with their mentors to this day and cite learning the importance of teacher leadership from these individuals. Carrying on the tradition of mentorship via supporting teacher leadership is foundational to the beliefs of the study's participants (Brown, 2003; Corcoran, Schwartz, \& Weinstein, 2012; Ingersoll \& Strong, 2011). 


\section{The Challenges of Teacher Leadership}

Creating teacher leadership is not without its challenges. The principals interviewed noted that when creating leadership opportunities for teachers, there is often a "missing piece" that some teachers possess. Some commonly mentioned areas for teacher growth were a lack of meaningful leadership experience, having the confidence to lead, and being able to learn from and rise above a series of setbacks. Additionally, the study's participants mentioned the challenge of providing equitable opportunities for all staff members to lead. Principals described the feeling of teachers perceiving others getting more chances to lead than them, what they described as "the haves and have nots," and that animosity sometimes arises when younger, less experienced teachers are seen as getting opportunities quickly. Despite these perceived teacher leadership pitfalls, the study's participants regularly noted that these issues, when teachers receive mentorship and guidance for improvement, can still grow into positive experiences (Brown, 2003; Corcoran, Schwartz, \& Weinstein, 2012; Ingersoll \& Strong, 2011).

\section{Consciously Cultivating Teacher Leadership}

Principals who promote teacher leadership utilize a variety of structures and systems in order to provide teachers and opportunity to grow and make an impact. Committee structures, like SBDM or a school-wide leadership committee, were mentioned by every principal who participated in the study. These formal structures allow teachers to have a direct voice and impact in issues ranging from school policy to instructional program reviews (Cheng \& Szeto, 2016; Cook, 2014; Klecker, Austin, \& Burns, 2000; Smith, Hayes, \& Lyons, 2017). 
Beyond committee structures, the study's participants also mentioned relying on Professional Learning Communities, or PLCs, as a means of giving teachers instructional leadership. The PLC structure, be it loose or tight, is extensively used to allow teachers to have a say in the instructional programming their students receive. This structure, when utilized appropriately, gives teachers the trust, support, and empowerment to teach their students effectively (DuFour, 2004; Scribner, Sawyer, Watson, \& Myers, 2007; Vanblaere \& Devos, 2016).

One structure that builds upon PLC work in schools that many principals use to promote teacher leadership is teacher-facilitated professional development. The study's participants noted that when teachers are given the opportunity to present and lead in learning for their peers, it not only builds their capacity for leadership, it also allows their fellow teachers to learn from a unique, and often times more authentic perspective. Pragmatically, this system can also be used as a more cost-effective way of getting all teachers professional development without sending an entire staff to a training and is often called a "train the trainer" model.

Lastly, principals who promote teacher leadership utilize multiple structures designed at receiving teacher feedback. These systems can be either formal, coming in the form of a feedback survey or online form, or informal, like simply identifying teachers in a building who a principal can trust to give them honest, candid information. Feedback systems are a rare mix of what Sinden, Hoy, and Sweetland (2004) note as "formalized" (the extent to which the organization has a codified set of rules, regulations, procedures, and policies), and "centralized" (the degree to which employees participate in decision making). By the study's participants ensuring that teachers had a way of having 
their feedback, voice, and input on decisions heard, they were able to positively and proactively address many issues before they arose.

\section{Implications}

There are numerous professional implications for this study's findings. These include areas for prioritization for struggling principals, structures and systems for teacher leaders to advocate for, and practical implications for principal preparation programs (Note: focus on Transformational Leadership theory and principal mentorship).

Since this study began, Kentucky's TELL survey was replaced with the Impact survey. Like the TELL Survey, Impact is a perception survey that gages teachers' perception on a variety of topics in their school: School Climate, School Leadership, Staff-Leadership Relationships, Managing Student Behavior, Feedback and Coaching, Professional Learning, and Resources. Principals who receive lower scores in the School Climate, School Leadership, and/or Staff-Leadership Relationships sections of the survey could greatly benefit from the findings of this study, from adopting some of the feedback protocols mentioned, to finding a meaningful way to build relationships with staff through believing teachers are capable of being empowered in their decision making. Furthermore, the fact that every participant mentioned the power of administrative mentorship (Augustine-Shaw \& Funk, 2013; Grissom, 2011) points to another strategy for principals to utilize who are struggling with teacher leadership. These leaders should consider reaching out to other principals through professional networking, educational cooperatives, or district or university partnerships to find a person to bounce ideas off of.

Just as principals can use the findings of this study to help address areas of deficiency in their schools, teachers can also use the information presented in this study. 
If a teacher is looking for meaningful ways to navigate increasing teacher voice and leadership in their building, some of the structures and beliefs mentioned here would be a great starting point to a conversation with their principal. The structures mentioned here, like feedback surveys and teacher leadership groups, could also be initiated by teachers, for teacher leadership can also exist even in the absence of administrative support (Cheng \& Szeto, 2016; Danielson, 2006; Greenier \& Whitehead, 2016).

Given how pivotal mentorship is to administrators of every experience level (Augustine-Shaw \& Funk, 2013; Clayton, Sanzo, \& Myran, 2012; Daresh, 2004; Grissom, 2011), the findings of this study can also be used to help influence principal preparation programs. Shaping principal preparation programs around giving aspiring administrators meaningful opportunities to observe, interview, or interact with principals who support teacher leadership could lead to a new generation of teacher-focused administrators. Furthermore, principal preparation programs could also put an increased emphasis on transformational leadership theory, as virtually every administrator in this study embodied characteristics associated with it (Burns, 1978).

\section{Researcher Reflection}

As I reflect upon my research, there are just as many implications for myself and my current practice as there are for my administrative colleagues and for principal preparation programs. When I started my dissertation journey several years ago, I was an eager assistant principal hoping to gain a fuller understanding of how principals shaped teacher leadership efforts, as I myself had two professional mentors who had emphasized its importance. One of my mentors described to me the idea of a leader knowing their "North Star," or their core belief about leadership in schools. I knew that my "North 
Star" was teacher leadership, but I wanted more context as to how to embody it with my actions.

Going through the dissertation process has helped me focus my leadership efforts. From reading numerous articles on the role of the administrator in teacher leadership efforts that have challenged my professional thinking, and through interviewing a dozen skilled, successful principals, it has allowed me to immediately begin to implement some of the practices the study's participants mentioned into my own school building-like intentionally cultivating relationships (Danielson, 2006; York-Barr \& Duke, 2004) and authentically creating systems for teacher feedback and participation (Angelle \& Schmid, 2007; Angelle \& Teague, 2014; Cheng \& Szeto, 2016).

The definition of teacher leadership that has emerged from my research has given me the "North Star" my mentors suggested I find. When I have found myself in a position to make a decision that connects to teacher leadership, I have found myself turning the definition into a series of questions, like, "How does this decision empower teachers impact their students?," "How can I build upon my staff's strengths via this new initiative?," and "How can I show my teachers that they are trusted and supported?" My dissertation journey has already had a professional impact on myself and my staff, and I hope that it can also assist other principals to empower those around them for the betterment of their school communities.

\section{Future Research}

Additional research is needed in the area of administration perceptions of teacher leadership. Future studies involving a larger sample size across a wider geographical area, studies involving the data from Kentucky's new Impact Survey, and studies of a 
different methodological focus would all garner more information about the power of administrative teacher leadership.

This study could be easily replicated in other areas of the state using pre-existing TELL survey data, which opens up the possibility of increasing the numbers of participants. Given the localized nature of this study, where twelve principals were interviewed in a specific geographical area in the state of Kentucky, a larger sample size could garner even more valuable information. Furthermore, this study could be broadened to a national, or even international scope to see if the results of this study truly transcend state and international lines, or if they are the result of more localized efforts and initiatives. Given the increased national focus on racial justice and equity, a future study that focused solely on minority principals who have found success promoting teacher leadership could be immensely beneficial and enlightening, and could explore issues as from minority teacher recruitment to community inclusion and efficacy.

With Kentucky's shift from the TELL Survey to the Impact Survey, this study could also be replicated using the results from the new system. If a future researcher used three of the Impact survey's categories-School Climate, School Leadership, and Staff-Leadership Relationships- to identify successful schools and principals, additional information about teacher leadership structures and beliefs could be identified.

Furthermore, there are multiple opportunities for studies of a different methodological focus to highlight details that this study could have missed. A researcher could decide to do either a single or multiple case study of schools where teacher leadership has been identified and could truly embed themselves into the school to witness the structures and beliefs about teacher leadership in action. Further 
phenomenological studies could also be done by broadening the sample group to principals, assistant principals, and even teachers to get a building-wide perspective on the impacts of administrative beliefs about teacher leadership. Potential quantitative studies could also be conducted by exploring a correlation between schools with high TELL or Impact scores and their student achievement scores.

\section{Conclusions}

This phenomenological study sought to understand the beliefs and building-level structures used by principals who consciously cultivate teacher leadership. The study's research questions were as follows:

Q1. How do administrators define teacher leadership?

Q2. What shared beliefs about teacher leadership exist among administrators who cultivate it?

Q3. What challenges emerge when creating teacher leadership opportunities?

Q4. How do administrators consciously cultivate teacher leadership?

Transformational Leadership Theory (Burns, 1978) was used as the study's theoretical framework. Twelve principals (four elementary, four middle, and four high school) were identified based on the most recent TELL survey data and took part in semistructured interviews with the goal of exploring the research questions identified.

The findings of this study are important for a number of reasons, but most importantly for how they can be immediately integrated into schools of every level. Principals of schools where teacher leadership efforts need to be improved upon can take the findings of this study and use them as a roadmap for increasing staff efficacy. The participants of this study all spoke to the power of collective teacher efficacy (Hattie, 
2015), and emphasized the immediate need for teacher leadership in every school. In the end, focusing on teacher leadership in schools will benefit all school stakeholders: teachers, parents, and-most importantly—students. 


\section{REFERENCES}

Alsbur, T.L., \& Hackman, D. G. (2006). Learing from experience: Initial findings of a mentoring/induction program for novice principals and superintendents. Planning and Changing, 37(3), pp.169-189.

Al-Yaseen, W.S., \& Al-Musaileem, Y. (2013). Teacher empowerment as an important component of job satisfaction: A comparative study of teachers' perspectives in Al-Farwaniya District, Kuwait. Compare: A Journal of Comparative and International Education, 45(6), 863-885.

Angelle, P.S., \& Schmid, JS. (2007). School structure and the identity of teacher leaders: Perspectives of principals and teachers. Journal of School Leadership, 17(6), 771-799.

Angelle, P.S., \& Teague, G. M. (2014). Teacher leadership and collective efficacy: Teacher perceptions in three US school districts. Journal of Educational Administration, 52(6), 738-753.

Augustine-Shaw, D., \& Funk, E. (2013). The influence of mentoring on developing leaders: Participants share their perspectives. Educational Considerations, 41(1), 19-26.

Berry, B. (2015). Teacherpreneurs: Cultivating and scaling up a bold brand of teacher leadership. The New Educator, 11(2), 146-160. 
Bourke, P. E. (2007). Inclusive education research and phenomenology. In Proceedings Australian Association for Research in Education. Research impacts: Proving or improving?, Fremantle, Western Australia

Brezica, K., Bergmark, U., \& Mitra, D.L. (2015). One size does not fit all: Differentiating leadership to support teachers in school reform. Educational Administration Quarterly, 51(1), 96-132.

Brown S. (2003). Working models: Why mentoring programs may be the key to teacher retention. Techniques: Connecting Education and Careers, 78(5), 18-21

Burns, J.M. (1978). Leadership. New York, NY: Harper \& Row

Bush, T. (2018). Preparation and induction for school principals: Global perspectives. Management in Education, 32(2), 66-71.

Carpenter, D. (2015). School culture and leadership of professional learning communities. International Journal of Educational Management. Center for Teaching Quality. (2018). Develop teacher leadership. Retrieved from https://www.teachingquality.org/our-services/collective-leadership/

Cheng, A.Y.N., \& Szeto, E. (2016). Teacher leadership development and principal facilitation: Novice teachers' perspectives. Teaching and Teacher Education, 58, $140-148$.

Childs-Bowen, D., Moller, G., \& Scrivner, J. (2000). Principals: Learners of leaders. NASSP Bulletin, 84, 27-34.

Clayton, J. K., Sanzo, K. L., \& Myran, S. (2013). Understanding mentoring in leadership development perspectives of district administrators and aspiring leaders. Journal of Research on Leadership Education, 8, 707-96. 
Cocek, C. (2012). Exploring education through phenomenology: A review of Gloria Dall'Alba's (Ed.) diverse approaches. Phenomenology and Practice, 6(1), 95105.

Cook, J.W. (2014). Sustainable school leadership: The teachers' perspective. National Council of Professors of Educational Administration Journal of Educational Leadership Preparation, 9(1), 103-119.

Corcoran, S. P., Schwartz, A. E., \& Weinstein, M. (2012). Training your own: The impact of New York City's aspiring principals program on student achievement. Educational Evaluation and Policy Analysis, 34(2), 232-253.

Cosenza, M.C. (2015). Defining teacher leadership: Affirming the teacher leader model standards. Issues in Teacher Education, 24(2), 79-99

Creswell, J.W. \& Poth, C.N. (2016). Qualitative inquiry and research design: Choosing among five approaches $\left(4^{\text {th }}\right.$ ed.). Thousand Oaks, CA: Sage Publications

Crowther, F., Kaagen, S.S., Ferguson, M., \& Hann, L. (2002). Developing teacher leaders: How teacher leadership enhances school success. Thousand Oaks, CA: Corwin Press

Danielson, C. (2006). Teacher leadership that strengthens professional practice. Alexandria: Association for Supervision and Curriculum Development Daresh, J. (2004). Mentoring school leaders: Professional promise or predictable problems? Educational Administration Quarterly, 40(4), 495-517.

Darling-Hammond, L., Bullmaster, M. L., \& Cobb, V. L. (1995). Rethinking Teacher Leadership through Professional Development Schools. Elementary School Journal, 96(1), 87-106. 
David, J. L. (1994). School-based decision making. Phi Delta Kappan, 75(9), 706.

Deal, T.E., \& Peterson, K.D. (2009). Shaping school culture: Pitfalls, paradoxes, \& promises. San Francisco, CA: Jossey-Bass Inc.

DeHann, E. \& Burger, Y. (2005). Coaching with colleagues. New York: Palgrave McMillan.

De Neve, D., \& Devos, G. (2017). Psychological states and working conditions buffer beginning teachers' intention to leave the job. European Journal of Teacher Education, 40(1), 6-27.

Donmoyer, R., Yennie-Donmoyer, J., \& Galloway, F. (2012). The search for connection across principal preparation, principal performance, and student achievement in an exemplary principal preparation program. Journal of Research on Leadership Education, 7, 5-43.

Drago-Severson, E. (2012). New opportunities for principal leadership: Shaping school climates for enhanced teacher development, Teachers College Record, 114, 1-44.

DuFour, R. (2004). What is a "professional learning community"? Educational Leadership, 61(8), 6-11.

Fuller, E. (2012). Examining principal turnover. National Education Policy Center. https://nepc.colorado.edu/blog/examining-principal-turnover

Greenier, V.T., \& Whitehead, G.E.K. (2016). Towards a model of teacher leadership in ELT: Authentic leadership in classroom practice. RELC Journal, 47(1), 79-95.

Grissom, J. A. (2011). Can good principals keep teachers in disadvantaged schools? Linking principal effectiveness to teacher satisfaction and turnover in hard-tostaff environments. Teachers College Record, 113(11), 2552-2585 
Harrison, C., \& Killion, J. (2007). Ten roles for teacher leaders. Educational Leadership, 65(1), 74-77.

Hattie, J. (2015). Visible learning: A synthesis of over 800 meta-analyses relating to achievement. New York, NY: Routledge.

Helterbran, V.R. (2008). Professionalism: Teachers taking the reins. The Clearing House, 81(3), 123-127.

Helterbran, V. R. (2010). Teacher leadership: Overcoming "I am just a teacher" syndrome. Education, 131(2), 363-371.

Hulpia, H., Devos, G., \& Van Keer, H. (2011). The relation between school leadership from a distributed perspective and teachers' organizational commitment: Examining the source of the leadership function. Education Administrator Quarterly, 47(5), 728-771.

Ingersoll, R. M., \& Strong, M. (2011). The impact of induction and mentoring programs for beginning teachers: A critical review of the research. Review of educational research, 81(2), 201-233.

Jantzi, D., \& Leithwood, K. (1996). Toward an explanation of variation in teachers' perceptions of transformational school leadership. Educational Administration Quarterly, 32.

Kane, B. D., \& Rosenquist, B. (2018). Making the most of instructional coaches. Phi Delta Kappan, 99(7), 21-25.

Katzenmeyer, M. H., \& Moller, G. V. (2001). Awakening the sleeping giant. Helping teachers develop as leaders (2nd ed.). Thousand Oaks, CA: Corwin. 
Kentucky Department of Education. (2015). Kentucky teacher leadership framework. Retrieved from https://education.ky.gov/teachers/Documents/Kentucky\%20Teacher\%20Leadersh ip\%20Framework.pdf

Klecker, B.M., Austin, J.L., \& Burns, L.T. (2000). An in-depth analysis of decisions made by Kentucky's school based decision making councils. Education, 120(4), 648-655.

Kouzes, J., \& Posner, B. (2012). The leadership challenge (5th ed.). San Francisco, CA: Jossey-Bass.

Krisko, M. E. (2001). Teacher leadership: A profile to identify the potential. Paper presented at the Biennial Convocation of Kappa Delta Pi, Orlando, FL.

Lambert, L. (2003). Leadership redefined: An evocative context for teacher leadership, School Leadership \& Management, 23(4), 421-430.

Liljenberg, M (2006). Teacher leadership modes and practices in a Swedish context - a case study. School Leadership and Management, 36(1), 21-40

Lindahl, R. (2008). Shared leadership: Can it work in schools? The Educational Forum, 72, 298-308.

Mangin, M.M. (2007). Facilitating elementary principals' support for instructional teacher leadership. Education Administration Quarterly, 43(3), 319-357.

Manna, P. (2015). Developing excellent school principals to advance teaching and learning: Considerations for state policy. New York: The Wallace Foundation, 2015 
Miles, M. B., Huberman, A. M., \& Saldana, J. (2014). Qualitative data analysis: An expanded sourcebook (3rd ed.). Thousand Oaks, CA: Sage Publications.

Minckler, C.H. (2014). School leadership that builds teacher social capital. Education Management Administration \& Leadership, 42(5), 657-679.

Murphy, J. (2005). Connecting teacher-leadership to school improvement. Thousand Oaks, CA: Corwin Press.

Neumerski, C.M. (2012). Rethinking instructional leadership, a review: What do we know about principal, teacher, and coach instructional leadership, and where should we go from here? Education Administration Quarterly, 49(2), 310-347. Onwuegbuzie, A.J., \& Collins, K.M.T. (2007). A typology of mixed methods sampling designs in social science research. Qualitative Report, 12(2), 281-316.

Poekert, P., Alexandrou, A., \& Shannon, D. (2016). How teachers become leaders: An internationally validated theoretical model of teacher leadership development. Research in Post-Compulsory Education, 21(4), 307-329.

Quaglia, R.J., \& Corso, M.J. (2014). Student voice: The instrument of change. Thousand Oaks, CA: Sage Publications.

Quaglia R. J., \& Lande, L.L. (2017). Teacher voice: Amplifying success. Thousand Oaks, CA: Sage Publications.

Raffanti, M. A. (2008). Leaders “Sitting Beside” Followers: A Phenomenology of Teacher Leadership. Journal of Ethnographic \& Qualitative Research, 3(1), 5868. 
Reeves, D. B. (2008). Reframing teacher leadership to improve your school. Alexandria, VA: Association for Supervision and Curriculum Development.

Required adoption of school councils for school-based decision making, Kentucky Revised Statute $106 \S 345$ (KRS 2017).

Scribner, J.P., Sawyer, K.R., Watson, S.T., \& Myers, V.L. (2007). Teacher teams and distributed leadership: A study of group discourse and collaboration. Education Administration Quarterly, 43(1), 67-100.

Sebastian, J., Allensworth, E., \& Huang, H. (2016). The Role of Teacher Leadership in How Principals Influence Classroom Instruction and Student Learning. American Journal of Education, 123, 69-108.

Sebastian, J., Huang, H., \& Allensworth, E. (2017). Examining integrated leadership systems in high schools: Connecting principal and teacher leadership to organizational processes and student outcomes. School Effectiveness and School Improvement, 28(3), 463-488.

Sinden, J., Hoy, W.K., \& Sweetland, S.R. (2004). Enabling school structures: Principal leadership and organizational commitment of teachers. Journal of School Leadership, 14(2), 195-210.

Smith, S.P., Hayes, M.L., \& Lyons, K.M. (2017). The ecology of instructional teacher leadership. The Journal of Mathematical Behavior, 46, 267-288.

Sergiovanni, T.J., \& Starratt, R. J. (1998). Supervision: A redefinition. Boston: McGrawHill

TELL Kentucky. (2020). About Tell Kentucky. https://tellkentucky.org/about 
Uribe-Florez, L.J., Al-Rawashdeh, A., \& Morales, S. (2014). Perceptions About Teacher Leadership: Do Teacher Leaders and Administrators Share a Common Ground? Journal of International Education and Leadership, 4(1), 1-15.

Valentine, J.W., \& Prater, M. (2011). Instructional, transformational, and managerial leadership and student achievement: High school principals make a difference. National Association of Secondary School Principals Bulletin, 95(1), 5-30.

Vanblaere, B., \& Devos, G. (2016). Relating school leadership to perceived professional learning community characteristics: A multilevel analysis. Teaching and Teacher Education, 57, 26-38.

Walkowiak, T.A. (2016). Five essential practices for communication: The work of instructional coaches. The Clearing House, 89(1), 14-17.

Wenner, J.A., \& Campbell, T. (2017). The theoretical and empirical basis of teacher leadership: A review of the literature. Review of Educational Research, 87(1), 134-171.

Williams, H.S., \& Johnson, T.L. (2013). Strategic leadership in schools. Education, 133(3), 350-355.

Yin, R.K. (2018). Case study research: Design and Methods $\left(6^{\text {th }}\right.$ ed $)$. Thousand Oaks, CA: Sage

York-Barr, J., \& Duke, K. (2004). What do we know about teacher Leadership? Findings from two decades of scholarship. Review of Educational Research, $74(3), 255-316$. 


\section{APPENDIX A \\ PARTICIPANT INTERVIEW QUESTIONS}

1. Tell me a little about yourself.

a. What brought you into education?

2. How long have you worked in education? Where did your educational career begin? What different positions have you held in education?

3. How do you define teacher leadership?

4. What role should teachers play in school decision making?

5. What does teacher leadership look like at your school?

a. Can you give me an example of a structure you established at your school? Is there a process that you have put in place that helped build teacher leadership?

6. How do you facilitate teacher leadership?

a. What intentional steps did you take to make teacher leadership happen?

7. What are the challenges involved with creating space for teacher leadership in schools?

8. What professional development have you taken part in that has aided you in teacher leadership efforts?

9. What support or mentorship have you received that has shaped your view of teacher leadership? 


\section{CURRICULUM VITA}

NAME: $\quad$ Adam Whitney Hicks

ADDRESS: Shelby County Public Schools

1155 West Main Street

Shelbyville, KY 40066

DOB: $\quad$ Effingham, IL - November 4, 1982

EDUCATION

\& TRAINING: $\quad$ B.A., Secondary English Education

University of Kentucky

2001-05

M.Ed., Secondary English Education

University of Kentucky

2005-06

National Board Certification

Secondary English Education

2012

Ed.S., Teacher Leadership

University of the Cumberlands

2013-14

Ed.D., Educational Leadership and Organizational Development University of Louisville 2017-21

AWARDS: Honorable Order of the Kentucky Colonels 2021

WHAS ExCel Award: Regional Teacher of the Year Shelby County Public Schols

2015

Golden Bell Award

Shelby County High School

2013 